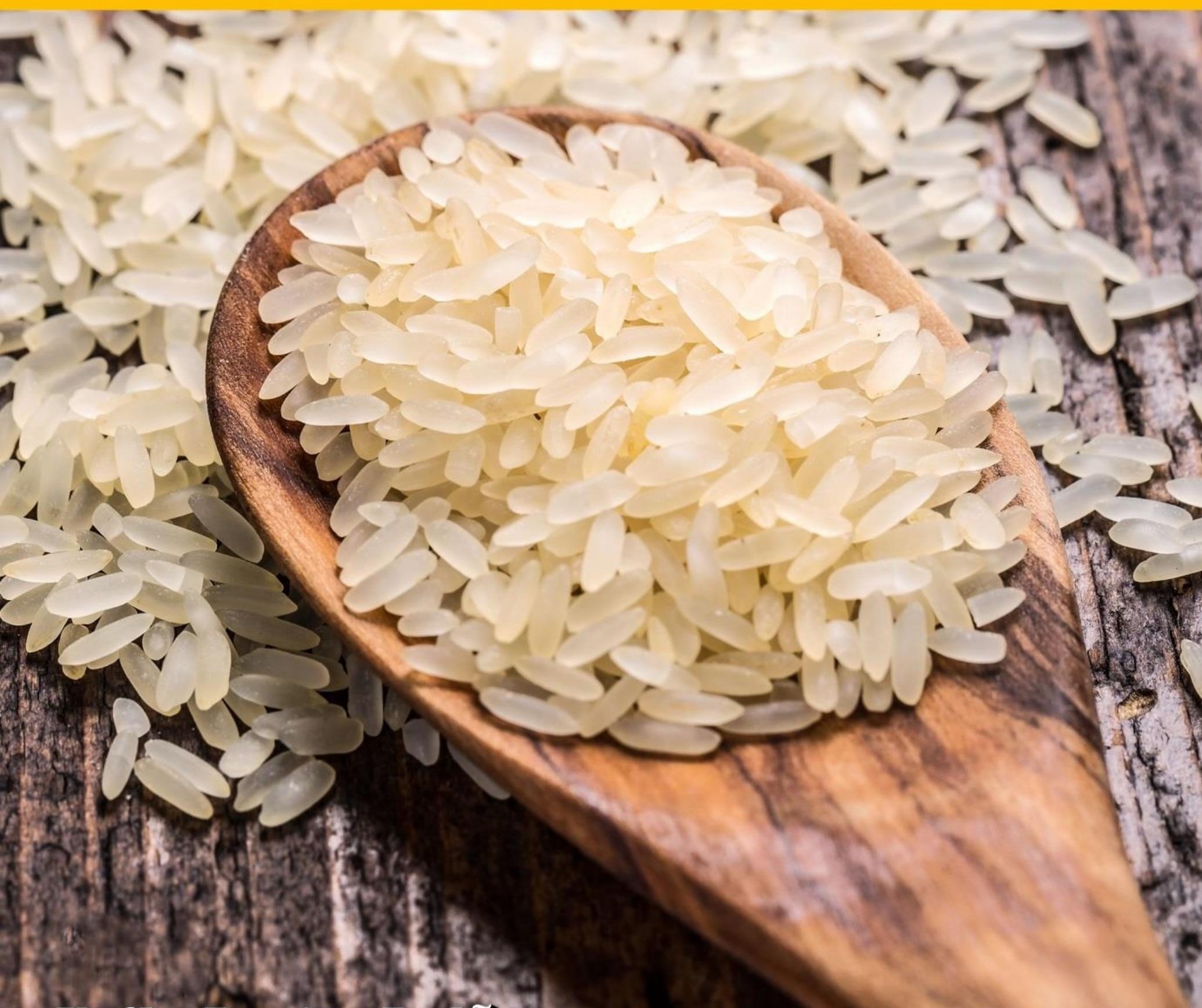

Kella Prates HDEGD

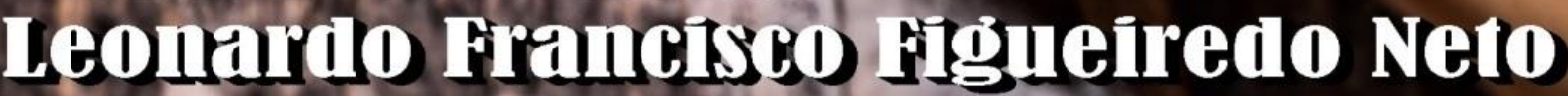

Boulngo Ritis ale fesiss sillya

Yasuilin casagraluita 
Editora Poisson

\title{
Análise de sustentabilidade na produção de arroz em Mato Grosso do Sul
}

\author{
1a Edição
}

Belo Horizonte

Poisson

2019 
Editor Chefe: Dr. Darly Fernando Andrade

\section{Conselho Editorial}

Dr. Antônio Artur de Souza - Universidade Federal de Minas Gerais

Msc. Davilson Eduardo Andrade

Msc. Fabiane dos Santos Toledo

Dr. José Eduardo Ferreira Lopes - Universidade Federal de Uberlândia

Dr. Otaviano Francisco Neves - Pontifícia Universidade Católica de Minas Gerais

Dr. Luiz Cláudio de Lima - Universidade FUMEC

Dr. Nelson Ferreira Filho - Faculdades Kennedy

Ms. Valdiney Alves de Oliveira - Universidade Federal de Uberlândia

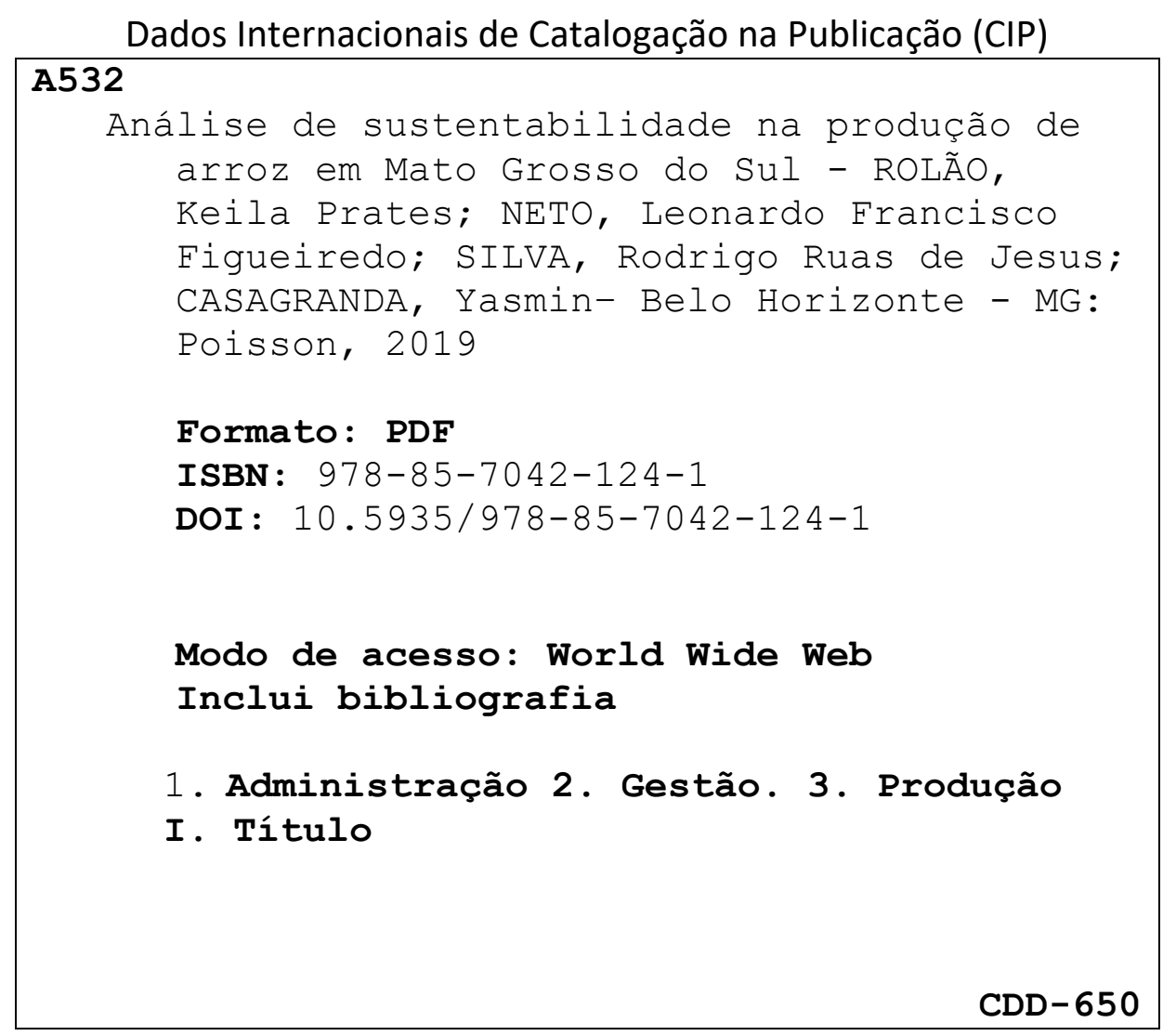

O conteúdo dos artigos e seus dados em sua forma, correção e confiabilidade são de responsabilidade exclusiva dos seus respectivos autores.

$\underline{\text { www.poisson.com.br }}$

contato@poisson.com.br 
Tudo posso, naquele que me fortalece!

Filipenses: 4:13 


\section{Autores}

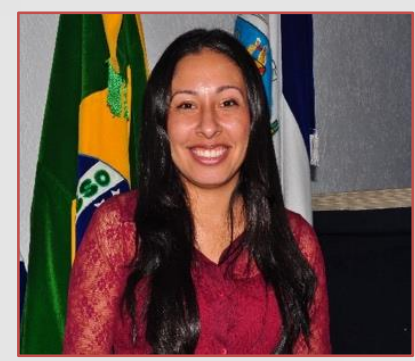

KEILA PRATES ROLÃO - Natural de Miranda-MS, em 2012 graduou-se em Administração pela Universidade para o Desenvolvimento do Estado e da Região do Pantanal (UNIDERP/Anhanguera). Em 2014 iniciou a especialização Educação em Direitos Humanos pela Universidade Federal de Mato Grosso do Sul (UFMS), cujo trabalho de conclusão foi defendido em 2016. Em 2018 ingressou no programa de mestrado em Administração da Universidade Federal de Mato Grosso do Sul (UFMS). Seus interesses de pesquisa são relativos aos diversos temas em Gestão financeira, Gestão Ambiental e Sustentabilidade, englobando tópicos do agronegócios, assim como, o produtor rural. Ênfase em pesquisas relacionadas a commodity arroz.

LEONARDO FRANCISCO FIGUEIREDO NETO - Possui graduação em Agronomia pela Universidade Federal do Espírito Santo (1990), mestrado em Ciências (Economia Aplicada) pela Universidade de São Paulo (1997) e doutorado em Engenharia (Engenharia de Produção) pela Universidade de São Paulo (2003). Atualmente é professor associado da Universidade Federal de Mato Grosso do Sul. Tem experiência na área de Engenharia de Produção, com ênfase em Avaliação de Projetos, atuando principalmente nos seguintes temas: gestão ambiental, agronegócio, logística reversa, sustentabilidade e agricultura familiar.
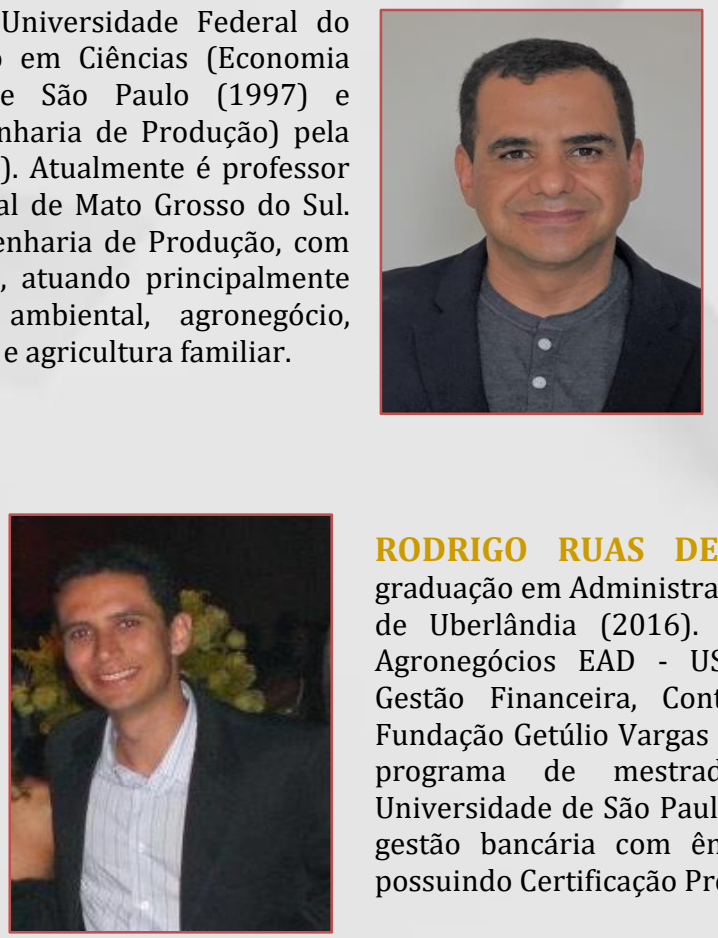

RODRIGO RUAS DE JESUS SILVA - Possui graduação em Administração pela Universidade Federal de Uberlândia (2016). Atualmente cursa MBA em Agronegócios EAD - USP/Esalq, e MBA Executivo: Gestão Financeira, Controladoria e Auditoria pela Fundação Getúlio Vargas - FGV. Em 2018 ingressou no programa de mestrado em Administração da Universidade de São Paulo (USP). Têm experiência em gestão bancária com ênfase em gerência comercial possuindo Certificação Profissional ANBIMA - Série 20.

YASMIN CASAGRANDA - Doutora e Mestre em Administração pela Universidade Federal de Mato Grosso do Sul (UFMS). Pós-graduada em Metodologias e Gestão para a Educação a Distância na Universidade Anhanguera Uniderp. Possui MBA em Gestão Empresarial pela Universidade Católica Dom Bosco. Graduada em Administração pela Universidade Federal de Mato Grosso de Sul. Possui experiência na área de Administração, Métodos Quantitativos e Qualitativos de Pesquisa em Gestão. Atua nas áreas de Administração de Empresas, Gestão Ambiental, Administração de Recursos Humanos e Análise Multivariada de Dados.

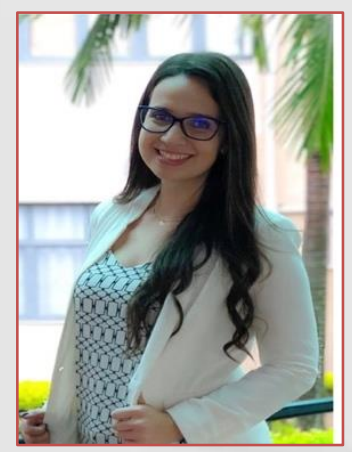




\section{Agradecimentos}

À Deus por tornar um sonho em realidade. Ao Senhor Leão Maldonado pelo apoio e incentivos financeiros. À Coordenação de Aperfeiçoamento de Pessoal de Nível Superior (CAPES) pelo fomento de pesquisa. 


\section{Prefácio}

A ideia de sustentabilidade se embasa nos conceitos iniciais de desenvolvimento sustentável e idealização dos processos produtivos voltados para a continuidade da população mundial. A partir essa proposta o entendimento de como pode ser aplicado o conceito a partir da relação entre o seu surgimento, desenvolvimento e instrumentos de verificação torna possível a evolução do conceito científico sobre a sua importância e constante necessidade de aprimoramento.

Diante dos apontamentos e da construção teórica desta obra é possível refletir sobre caminhos que se pode seguir com o objetivo de alcançar uma produção sustentável. Torna-se, portanto, parte da agenda dos pesquisadores o conceito de sustentabilidade relacionado com métodos de mensuração e quantificação dos dados para comprovação dos achados. Essa relação pode ser vista nos resultados.

É possível determinar uma nova era de conceitos a partir do que foi encontrado. Indicadores em destaques pontuais como os resíduos sólidos estão colocados nas discussões mundiais sobre a sustentabilidade e podem auxiliar na determinação do quão desenvolvido um país é considerado, tendo em vista sua preocupação com o impacto deste não somente na dimensão econômica das suas atividades, mas também no impacto que pode causar na dimensão social.

Uma visão voltada apenas para uma das dimensões, seja ambiental, econômica ou social, pode levar a erros de interpretação e posteriormente à necessidade de novas análises em novas dimensões criadas para preencher as lacunas teóricas. Quando se analisa uma parte econômica é determinante a sua relação social e também ambiental para que os resultados medidos possam apresentar validade real e então permitam uma comparação com o cenário considerado ideal para a teoria.

Assim se dá a essência desta leitura, o ideal da sustentabilidade aplicado à produção de arroz no estado de Mato Grosso do Sul. O desenvolvimento do raciocínio sobre os primeiros passos da reflexão em torno do meio ambiente e suas propostas de aplicação prática voltadas para a realização de experimentos com dados para que se possa tomar decisões que englobem a preocupação ambiente, a busca pela melhor configuração de resultados econômicos e a relação de todas essas variáveis com o nível social da comunidade que os cerca.

\section{Yasmin Casagranda}




\section{SUMÁRIO}

Capítulo 1: Introdução 09

Capítulo 2: Revisão da Literatura. 13

Capítulo 3: Procedimentos Metodológicos.. 24

Capítulo 4: Discussão e Apresentação dos Dados 30

Capítulo 5: Resultados. 38

Capítulo 6: Considerações Finais. 38 
Introdução 


\section{INTRODUÇÃO}

É apresentada, nesta parte do livro, como foi desenvolvida a pesquisa, apoiando-se, na revisão da literatura e suas considerações relacionadas ao tema de estudo. Nesta óptica, os subitens refere-se ao contexto em que essa pesquisa se insere, os objetivos (geral e específicos) com a finalidade de alcançar os fatores anteriormente pré-estabelecidos. Entretanto, a justificativa evidencia a importância deste trabalho ter sido desenvolvido. Finalmente, apresenta-se o resumo de cada etapa utilizada neste estudo, ou seja, a estrutura do trabalho.

\subsection{CONTEXTUALIZAÇÃo}

A humanidade alcançou seu primeiro bilhão de habitantes em 1802, de acordo com o levantamento de dados da Organização das Nações Unidas (ONU, 1997), e, destarte estimativas, a população mundial em breve atingirá nove bilhões de habitantes. Entretanto, o Balanço Contábil das Nações (KASSAI et al., 2008), o planeta não suportará essa população se os modelos atuais de extração, produção, distribuição, consumo e descarte continuarem alicerçados nas crenças e valores estabelecidos no século XX, onde o capitalismo enfatiza que o melhor desempenho econômico é com o aumento da produtividade com exploração desordenada da natureza e ampliação das desigualdades econômica e social (ROCHA; SIMAN, 2005).

Nesta perspectiva, o tema sustentabilidade planetária emerge como premissa do reconhecimento da assimetria econômica, social e ambiental. Existe na literatura um senso comum de triple bottom line para entender e praticar sustentabilidade (Elkington, 2012; Hart \& Milstein, 2003; Nidomulu, Prahalad \& Rangaswami, 2009; Porter \& Kramer, 2011). A dimensão econômica inclui não só a economia formal, mas também as atividades informais que provêem serviços para os indivíduos e grupos e aumentam, assim, a renda monetária e o padrão de vida dos indivíduos (ALMEIDA, 2002). Estudos e pesquisas desenvolvidos por diversos autores (KASSAI et al., 2008; LOUETTE, 2008; TINOCO e KRAMER, 2008; LOUETTE, 2009) discutem os efeitos desregulados do desenvolvimento econômico quando não há conservação adequada dos recursos naturais. É muito frequente observar, somente, a relação aos aspectos ambientais/ecológicos da alimentação, importantíssimos, porém não únicos. É relevante considerar os aspectos culturais, sociais e econômicos da sustentabilidade do sistema alimentar (Ribeiro et al, 2107).

A dimensão ambiental ou ecológica estimula empresas a considerarem o impacto de suas atividades sobre o meio ambiente, na forma de utilização dos recursos naturais, e contribui para a integração da administração ambiental na rotina de trabalho (ALMEIDA, 2002). A dimensão social perfaz no aspecto social acondicionado às qualidades dos seres humanos, como suas habilidades, dedicação e experiências, abrangendo tanto o ambiente interno da empresa quanto o externo (ALMEIDA, 2002).

Os debates sobre sustentabilidade têm como proposito investigar as múltiplas relações, causas e impactos de um problema complexo e, deste modo, buscar uma solução estratégica através da construção de opções apropriadas de política para o problema em questão (ROTMANS, 2006).

Entre outros desafios para o desenvolvimento econômico brasileiro, está o crescimento da produção agropecuária e, concomitantemente, reduzir os impactos dessa produção sobre os recursos naturais. 0 Brasil é considerado um dos países que mostram condições de expandir a produção agropecuária para prover a demanda mundial por alimentos e biocombustíveis. Entretanto, muitas barreiras ainda precisam ser suplantadas para que esse crescimento do setor aconteça de uma maneira sustentável, gerando não apenas benefícios econômicos para o país, mas também assegurando a conservação da sua grande riqueza de recursos naturais e viabilizando melhores condições de vida para as pessoas envolvidas na produção do setor (Sambuichi et al.; 2012).

A sustentabilidade na produção de alimentos tem seu suporte na rentabilidade e nos impactos sobre recursos naturais e consequências sociais. 0 produtor rural tem a propriedade da terra, mas depende de conhecimento, atitudes e parcerias para atender as demandas do mercado. Neste contexto, a produção de arroz (Oryza sativa L.) é proeminente, visto que é um dos alimentos com melhor balanceamento nutricional, fornecendo $21 \%$ da energia e $15 \%$ da proteína per capita necessária ao homem (OLI ET AL. 2014).

\subsection{OBJETIVO GERAL}

Analisar o desempenho de indicadores nos três pilares de sustentabilidade das fazendas produtoras de arroz irrigado, no Pantanal Sul-Mato-Grossense. 


\subsubsection{OBJETIVOS ESPECÍFICOS}

Realizar uma busca na literatura disponível dos principais frameworks e indicadores de sustentabilidade utilizados na produção de arroz nos três pilares (ambiental, econômico e social);

Identificar a sustentabilidade da produção de arroz no Pantanal Sul-Mato-Grossense com base no framework selecionado;

Caracterizar a rizicultura no Pantanal Sul-Mato-Grossense a partir das suas estratégias sustentáveis de acordo o framework selecionado;

\subsection{QUESTÕES DE PESQUISA}

A presente pesquisa pretende responder a algumas vertentes no que se refere aos indicadores de sustentabilidade sendo assim, as questões principais que norteiam este estudo são:

Quais os níveis das dimensões de sustentabilidade nas propriedades analisadas?

Quais os indicadores que influenciam sobre o termo sustentabilidade?

\subsection{JUSTIFICATIVA DO TEMA}

Neste contexto, nota-se que mais à frente da importância de expressão social e econômica que esse ramo do agronegócio possui, simultaneamente, há um cuidado universal de produção alimentar nos pilares ambiental, econômico e social, que são apoiados no Triple Botton Line (people, profit and planet). Estabelecendo-se vital, logo, o fornecimento de arroz à população com base em uma produção com fatores sustentável. Estimulando, à vista disso, o progresso da temática da sustentabilidade na produção de arroz sobre a óptica estratégica da gestão de operações sustentáveis.

Dessa forma, os indicadores são elaborados como forma de analisar e amenizar procedimentos heterogêneos, em níveis geograficamente definidos, tais como países e regiões (MARTIN, 2002; VELAZCO, 2015). Há uma diversidade de listas e frameworks de indicadores de sustentabilidade (RANGANATHAN, 1998; BINDER; FEOLA; STEINBERGER, 2010; COSTA, 2010; VAN PASSEL; MEUL, 2012) apresentando complexidade metodológica (SINGH ET AL., 2012; VAN PASSEL; MEUL, 2012), todavia, ainda são mínimas as pesquisas que mensuram a sustentabilidade empresarial (VELEVA; ELLENBECKER, 2001; SINGH et al., 2009). No entanto, a ausência consensual do termo sustentabilidade (RIGBY ET AL., 2001; CLARO; CLARO, 2004; LABUSCHAGNE; BRENT; VAN ERCK, 2005, BOND; MORRISON-SAUNDERS, 2011) e também avaliação nos três pilares de sustentabilidade (CLARO; CLARO, 2004; KRAJNC; GLAVIC, 2005; SZÉKELY; KNIRSCH, 2005; SINGH ET AL., 2009; BUYS ET AL., 2014).

A necessidade de um método de mensuração da sustentabilidade em organizações no Tripé de Sustentabilidade: ambiental, econômico e social (CALLADO, 2010; BUYS ET AL., 2014; VELAZCO, 2015; MELO, 2015) traz consigo a relevância da presente pesquisa, pois é efetivo a reivindicação por um método de mensuração da sustentabilidade, que seja acessível a diferentes públicos (RIERSNESS ET AL., 2007; ACOSTA-ALBA; VANDER WERF, 2011; VELAZCO, 2015;).

O Departamento de Agricultura dos Estados Unidos (USDA, 2018) avalia o cultivo de arroz (Oryza sativa L.) no Brasil, sendo o maior produtor e consumidor mundial de arroz entre os países não asiáticos, produziu 7,21 milhões toneladas deste cereal na safra 2015/2016. De acordo com os relatórios da Organização para a Alimentação e Agricultura (FAO) em 2017, a produção anual de arroz é de aproximadamente 759,6 milhões de toneladas (FAO, 2018).

Na safra 2016/2017, a produção de arroz no Rio Grande do Sul assume relevante papel em termos de produção que apontam uma área total de 1.100,7 milhões de hectares plantadas (CONAB, 2018). Nesta área, que equivale a $41 \%$ do total nacional, são colhidos mais de $55 \%$ da produção de arroz do Brasil (CONAB, 2018). É importante destacar que dentre as regiões produtoras de arroz, o Mato Grosso do Sul, participa com uma área de colheita 15.342 hectares, apresentando-se uma produtividade de 98.608 toneladas e rendimento médio previsto de $6.427 \mathrm{~kg} / \mathrm{hectares}$ (IBGE, 2017).

Neste sentido, pautando-se no supracitado, tem-se relevância do tema e da problemática, as principais contribuições deste estudo ressaltam-se o caráter inédito da avaliação da sustentabilidade numa amostra considerável de fazendas produtoras de arroz no Pantanal Sul-Mato-Grossense, serão analisados pontos 
fortes e fracos do espaço amostral, consequentemente, ponto de vista para atingir os níveis estimados de sustentabilidade por essas riziculturas. Da mesma maneira, compreender o processo de sustentabilidade em virtude de características, estruturais, gerenciais e tecnológicas das riziculturas pesquisadas. 0 instrumental empregado será desenvolvido com finalidade de proporcionar um framework para avaliação da sustentabilidade em riziculturas no nível local, regional e nacional. Acredita-se que essa pesquisa é importante devido a atender uma parcela específica: produtor rural, no caso o rizicultor; Associação de Produtores de Arroz e Irrigantes de Mato Grosso do Sul (APAI). Consequentemente, uma contribuição para a academia, sociedade agrícola e para o crescimento pessoal da pesquisadora.

\subsection{ESTRUTURAÇÃO DO TRABALHO}

Esta pesquisa se divide em cinco capítulos, além da Introdução. Nesta perspectiva cabe destacar os procedimentos adotados em cada uma dessas etapas, com o propósito de descrever os critérios abordados em cada uma.

Na Introdução, é realizada uma abordagem, de forma suscita, percorrendo o modo como cada capítulo foi estruturado, demonstrando-se o contexto e os objetivos da pesquisa. Destarte, é apresentada a justificativa e a relevância do tema, indicando como este estudo contribuirá para a aplicação prática. Além, das questões norteadoras.

No capítulo 2, é apresentada a revisão da literatura sobre a sustentabilidade e a produção de arroz, na sequencia o panorama internacional e nacional da produção de arroz, assim como se dá o cultivo da cultura de arroz.

No capítulo 3, são apresentados os procedimentos metodológicos onde foi realizado a analytic hierarchy process - AHP, a qual permitiu que fosse identificado o nível de sustentabilidade, em termos da produção de arroz em Mato Grosso do Sul.

No capítulo 4, aborda a discussão da metodologia na análise paritária pelo AHP suas técnicas de agregação, ponderação e formação de índices dos indicadores para cada nível da dimensão sustentável.

No capítulo 5, demonstra os resultados obtidos no decorrer da pesquisa referente ao nível de sustentabilidade nos três pilares da dimensão: ambiental, econômico e social.

E, por fim, o capítulo 6 apresenta as Considerações Finais do presente estudo, abordando a que resultados a pesquisa chegou, apresentando se sim ou não sustentável objeto de estudo desta pesquisa. 


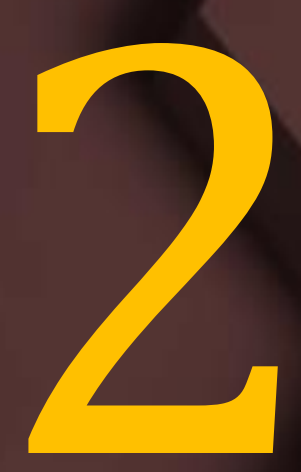

Revisão da

Literatura 


\section{REVISÃO DA LITERATURA}

Este capítulo apresenta uma discussão do tema da sustentabilidade na produção de arroz, além de abordar a complexidade da elaboração de indicadores de sustentabilidade utilizados para a avaliação, acompanhamento e gerenciamento desse setor. Em seguida, também são apresentados alguns frameworks nacionais e internacionais que foram desenvolvidos para a avaliação da sustentabilidade.

\subsection{SUSTENTABILIDADE}

A conjuntura social, política e econômica em que está implantada a maioria das atividades do agronegócio, vêm ocorrendo expressivas mudanças nas últimas décadas, a saber: mercados globalizados, desenvolvimento tecnológico e industrial e crescimento econômico (CASAROTTO FILHO; PIRES, 1998; LUDWIG, 2004). 0 avanço social e o crescimento econômico estão aliados às atividades desempenhadas pelas empresas, vinculando-se aos impactos negativos ao meio ambiente, em virtude do disparato uso de recurso não renováveis, uso abundante de recursos renováveis, contaminação da terra e água e difusão de gases de efeito estufa (GUTBERLET, 2000).

Concomitantemente, relatórios de projeções de consumo e demanda de alimento correspondente ao crescimento econômico e populacional foram emitidos e publicados em âmbitos internacionais. Esses relatórios buscam responder às seguintes perguntas: "Qual a demanda alimentar nos próximos anos?", "Qual o responsável por alimentar o mundo?", "Como se pode suprir essa realidade demandada?", "Qual a produção para suprir a demanda futura?", "Como produzir com ações sustentáveis?", entre outras. Proposições utilizadas com frequência no dia-a-dia, mas de difícil resolução (VELAZCO, 2015).

Entretanto, a Comissão Mundial sobre Meio Ambiente e Desenvolvimento (1987, p. 40), a primeira a definir o conceito de sustentabilidade como "desenvolvimento que satisfaz as necessidades do presente sem afetar a capacidade das gerações futuras de satisfazerem as suas próprias necessidades". A definição de produção sustentável somente foi estabelecida em 1992, na Conferência das Nações Unidas sobre Meio Ambiente e Desenvolvimento conhecida como Rio 92, após a conclusão que a degradação constante do meio ambiente é medidas insustentáveis de consumo e produção. Concomitantemente, teve como resultado a produção de alguns documentos oficiais em razão de sensibilizar a sociedade e as vias políticas (UNITED NATIONS, 1992). A Agenda 21 é um marco na história de evolução para o Século XXI, baseada entre aspectos ambientais, sociais e econômicos, quer dizer, a sustentabilidade (CALLADO, 2010).

Partindo-se dessa concepção, diversas empresas que anteriormente utilizam apenas indicadores financeiros para mensurar os resultados das atividades contábeis, passaram a adotar ações sustentáveis devido às reivindicações de diferentes públicos (consumidores, fornecedores, empregados, agências nacionais e internacionais, instituição bancária, companhia de seguros, acionistas, associações comerciais e comunidade local), em consequência, a procura por produtos apontados saudáveis (EPSTEIN; ROY, 2001; VELEVA; ELLENBECKER, 2001; DEON, 2002; HART; MILSTEIN, 2004; KRAJNC; GLAVIC, 2005; VELAZCO, 2015). Essa conviç̧ão desencadeia no princípio do Triple Bottom Line (People, Planet e Profit), chamado em português de Tripé da Sustentabilidade, que consiste em garantir o futuro da disponibilidade das opções econômicas, ecológicas e sociais (ELKINGTON, 1998). Dentro desta óptica multidimensional requisita que a dimensão econômica seja acessível, a social tenha conformidade e a ambiental apresente eficiência estrutural (GERDESSEN; PASCUCCI, 2013).

O terno Sustentabilidade, ou desenvolvimento sustentável, tornou-se conhecido a partir de 1987, quando foi cunhado pela World Commission on Environment and Development (WCED - Comissão Mundial sobre Meio Ambiente e Desenvolvimento das Nações Unidas) em seu relatório Our common future (Nosso futuro comum), também chamado como Relatório Brundtland. Desde esse período, o conceito de desenvolvimento sustentável, passou a constatar constantemente a linguagem internacional, tornando-se norte central de pesquisas realizadas por organismos multilaterais e ainda por grandes empresas (WCED, 1987).

Diferentes princípios e diretrizes internacionais e/ou tratados internacionais abordam a sustentabilidade:

- Diretrizes da Organização para a Cooperação e o Desenvolvimento Econômico (OCDE);

- Organização das Nações Unidas (ONU);

- Pacto Global do PNU - Programa das Nações Unidas para o Desenvolvimento (PNUD);

- Metas do Milênio - têm como objetivo o Desenvolvimento do Milênio (ODM) da ONU; 
- Carta da Terra - proposta da Cúpula da Terra no Rio de Janeiro, no ano de 1992;

- Agenda 21 -lançada oficialmente durante a Rio-92;

Os autores Spangenberg \& Bonniot (1998) rotulado seus princípios de sustentabilidade como "dimensões da sustentabilidade". Estas dimensões são denominadas "prisma da sustentabilidade", estão representadas na figura 1.

Figura 1. 0 prisma da sustentabilidade

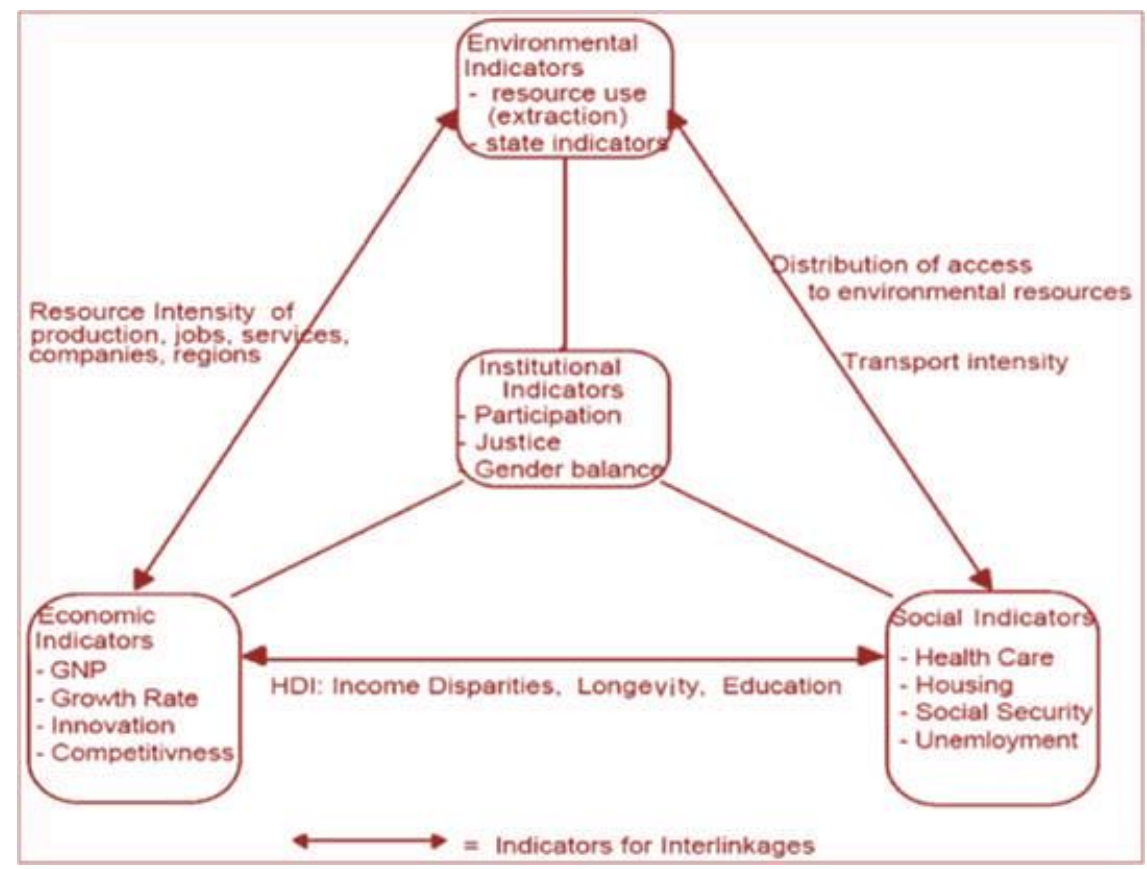

Fonte: Spangenberg \& Bonniot, 1998.

Segundo Claro, Claro e Amâncio (2008) entendem que a dimensão ecológica, ou ambiental, pode ser dividida em três sub dimensões: primeiramente, inclui ecologia, diversidade do hábitat e florestas; segundo, a qualidade do ar e da água (poluição), e a proteção da saúde humana por meio da minimização de contaminação química e da poluição; e terceiro, a conservação de recursos renováveis e não renováveis.

De acordo com os estudos de Groot (2002) e de Spangenberg e Bonniot (1998) subdividem a sustentabilidade ambiental, tais como:

- Ciência ambiental, diversidade do habitat e florestas;

- Poluição, da qualidade do ar e da água;

- Conservação e administração de recursos renováveis e não renováveis.

A dimensão social refere-se às qualidades dos seres humanos, como suas habilidades, sua dedicação e suas experiências, e engloba tanto o ambiente interno da empresa quanto o externo. No que tange ao agronegócio o uso de agrotóxicos, um ou mais produtores são as fontes geradoras, enquanto os demais indivíduos são os receptores das externalidades negativas.

Nesta perspectiva, Soares \& Porto $(2007$, p.3) esclarece:

"florestas são desmatadas, rios e solos são poluídos, trabalhadores e consumidores são contaminados, e as doenças e mortes frequentemente invisíveis no conjunto das estatísticas de saúde acabam sendo coletivamente absorvidas pela sociedade e pelos sistemas públicos previdenciários e de saúde" (SOARES; PORTO, 2007, p.3). 
Segundo Claro, Claro e Amâncio (2008), a dimensão econômica aborda não só a economia formal, incorpora as atividades informais que proveem serviços para os indivíduos e grupos e aumentam, assim, a renda monetária e o padrão de vida dos indivíduos.

De acordo com Soares e Porto (2007, p.3):

“a competição entre agentes econômicos (e entre países e regiões num plano comercial mais global) por melhores preços oferecidos ao 'mercado', longe de otimizar o funcionamento da economia, pode constituir-se num dos maiores entraves para a sustentabilidade do desenvolvimento, pois externaliza diversos custos sociais, ambientais e sanitários que permanecem ocultos nos preços das mercadorias e terminam por serem socializados"

Diversos estudos e pesquisas desenvolvidos por vários autores (KASSAI et al., 2008; LOUETTE, 2008; TINOCO e KRAMER, 2008; LOUETTE, 2009) discorrem sobre os efeitos negativos onde o desenvolvimento econômico perante a conservação da natureza. Dessa forma, o Instituto dos Auditores Independentes do Brasil (IBRACON, 1996) aprovou, a Norma de Procedimento de Auditoria NPA 11, que visa:

“Estabelecer os liames entre a Contabilidade e o Meio Ambiente, tendo em vista que, como as demais ciências, incumbe-lhe também participar dos esforços em favor da defesa e proteção contra a poluição e as agressões à vida humana e à natureza" (IBRACON, 1996, p.1).

Uma empresa sustentável é aquela que contribui para o desenvolvimento sustentável ao gerar, simultaneamente, benefícios econômicos, sociais e ambientais - conhecidos como os três pilares do desenvolvimento sustentável (Hart \& Milstein, 2004). A inserção dos três pilares da sustentabilidade tanto na pesquisa como nas práticas de gestão foram e ainda são de extrema importância na consideração dos impactos ambientais, sociais e econômicos da atuação das empresas na sociedade. Esses pilares permitem ainda que as empresas encontrem as oportunidades derivadas dos problemas ambientais e sociais. Sem dúvida, percebe-se um grande avanço no que tange às práticas de gestão sustentável no ambiente corporativo.

\subsection{PRODUÇÃO DE ARROZ E SUSTENTABILIDADE}

Para Ferreira (2008), ainda que as ideias do desenvolvimento sustentável esteja se alastrando, existem diversas dificuldades para debater a sustentabilidade, sobretudo quando se trata da produção de grãos. Dentre os vários obstáculos, destaca-se: i) controvérsias entre correntes de pensamentos que podem motivar o entendimento diferenciado da sustentabilidade entre os atores da cadeia produtiva; ii) aceitação e interesse pela sustentabilidade dependem da estrutura e dos valores da sociedade; iii) práticas e insumos evidenciam impactos desiguais em função do solo, clima e outros fatores não controláveis pelos seres humanos; iv) dificuldade para mensurar questões humanas e de família, presentes de modo relevante em atividades agrícolas; v) dificuldade para se alcançar um equilíbrio geral, considerando-se que as transformações devem ocorrer em nível de propriedades rurais, repercutindo na sustentabilidade da região e, assim, gradativamente, até atingir a escala nacional. 
Figura 2 - Sistema de produção de grãos.

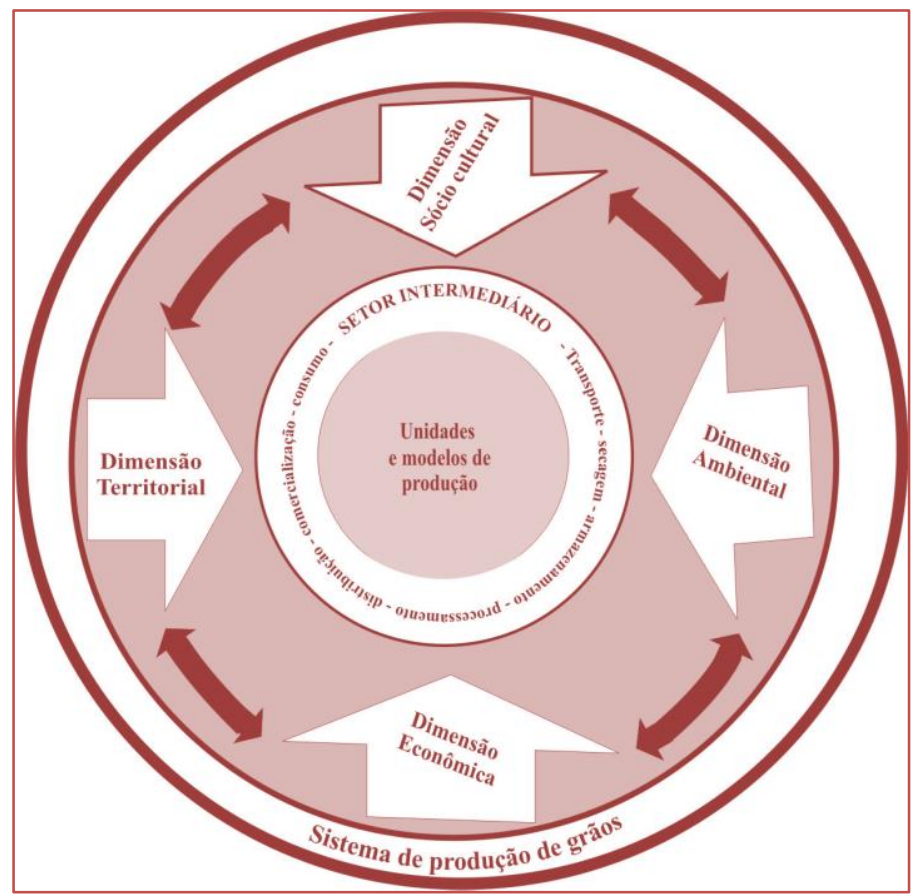

Neste cenário, o agronegócio se destaca por propiciar bens alimentar e como operador de mudanças no meio ambiente correspondente ao uso intenso de recursos naturais (YUNLONG; SMIT, 1994). A rizicultura representada pelo cultivo de arroz necessita de elementos humanos e climáticos, é vista com um processo de constante transformação, dinâmico e, denota vários obstáculos no decorrer da sua trajetória, tais como: entender os métodos existentes nesse procedimento, solos com peculiaridades prejudicando o plantio e, assim como, a produção, bem como a vulnerabilidade a riscos climáticos e entre outros fatores (ZYLBERSZTAJN, 1993; FINGER, 2012; HAEFELE; NELSON; HIJMANS, 2014; CONAB, 2015; EPAGRI, 2016; SILVA, 2016).

As fazendas produtoras de arroz irrigado enfrentam um número significativo de desafios associados às questões ambientais. Os agentes fiscalizadores, gestores e stakeholders, trabalham com finalidade de limitar o uso de agrotóxicos. Além da degradação de paisagem, esgotamento de mananciais de água, contaminação da água, diminuição de fauna e flora nativa integrada, assim como a extinção e redução dos habitats de biomas e ecossistemas brasileiros (CONAB, 2015).

Nota-se na população a adoção de uma alimentação mais saudável, essa ideologia se confirma na bibliografia com pesquisas realizadas no rumo das inovações genéticas, cultivo do arroz orgânico, biodinâmico e até agroecológico (BARBOSA, 2014; CONAB, 2015). Pretty et. al (2005) enfatiza que é preciso reexaminar os sistemas produtivos dentro da perspectiva da sustentabilidade, dessa forma buscase ir à frente, reconsiderando os mesmos propósitos, o sistema de consumo. A produção projetada brasileira de arroz para 2026/27 é de 12,6 milhões de toneladas, e um consumo de 11,5 milhões de toneladas (SPA/MAPA, 2017).

Destarte, para que esse progresso aconteça e tangência a segurança alimentar será imprescindível seguir o desempenho no setor, tendo em vista elevar a produtividade agrícola e, para tanto será essencial o adequado gerenciamento e percepção das variáveis que integra os sistemas de produção e comercialização do arroz (QUILTY ET AL., 2014). Mediante a elaboração e supervisão dos desempenhos de indicadores de sustentabilidade, seja viável verificar e monitorar as modificações que acontecem no processo produtivo e detectar até que ponto estas alterações estão apresentando eficiência na dimensão social, econômica e ambiental (CALLADO, 2010).

Ao analisar as riziculturas quanto à sustentabilidade, segundo Van Passel et al. (2007) preconiza que o entendimento dos indicadores transpassam tanto a prática de atividade quanto a performance sustentável é fundamental para que o agronegócio efetive a sustentabilidade. Este domínio dos indicadores promove a análise de aproximação ou afastamento dos escopos sustentáveis a serem conquistados e, 
consequentemente, facilita na responsabilidade política de todos os autores inclusos no setor referente à produção sustentável (MELO, 2015).

Fatores ligados à avaliação de sustentabilidade por meio de indicadores incorporados ou índice demandam a assimilação de um número significativo de conhecimento proveniente de várias áreas da ciência (CALLADO, 2010). A mensuração de sustentabilidade continua em progresso de pesquisas com finalidade de que o conhecimento científico agregado sobre o tema se torne harmônico, compacto e menos intangível, de maneira clara e objetiva na transmissão dessas informações a um público não especialista. (AZEVEDO, 2002; BRAGA ET AL., 2004; SEARCY; KARAPETROVIC; MCCARTNEY, 2005; DAHL, 2007).

Preconiza Veleva et al. (2001), que o desenvolvimento e a pratica dos indicadores é preciso a cooperação entre as organizações, comunidades e governos em diferentes esferas (local, regional, nacional e internacional).

Figura 3- Acompanhamento de indicadores de sustentabilidade.

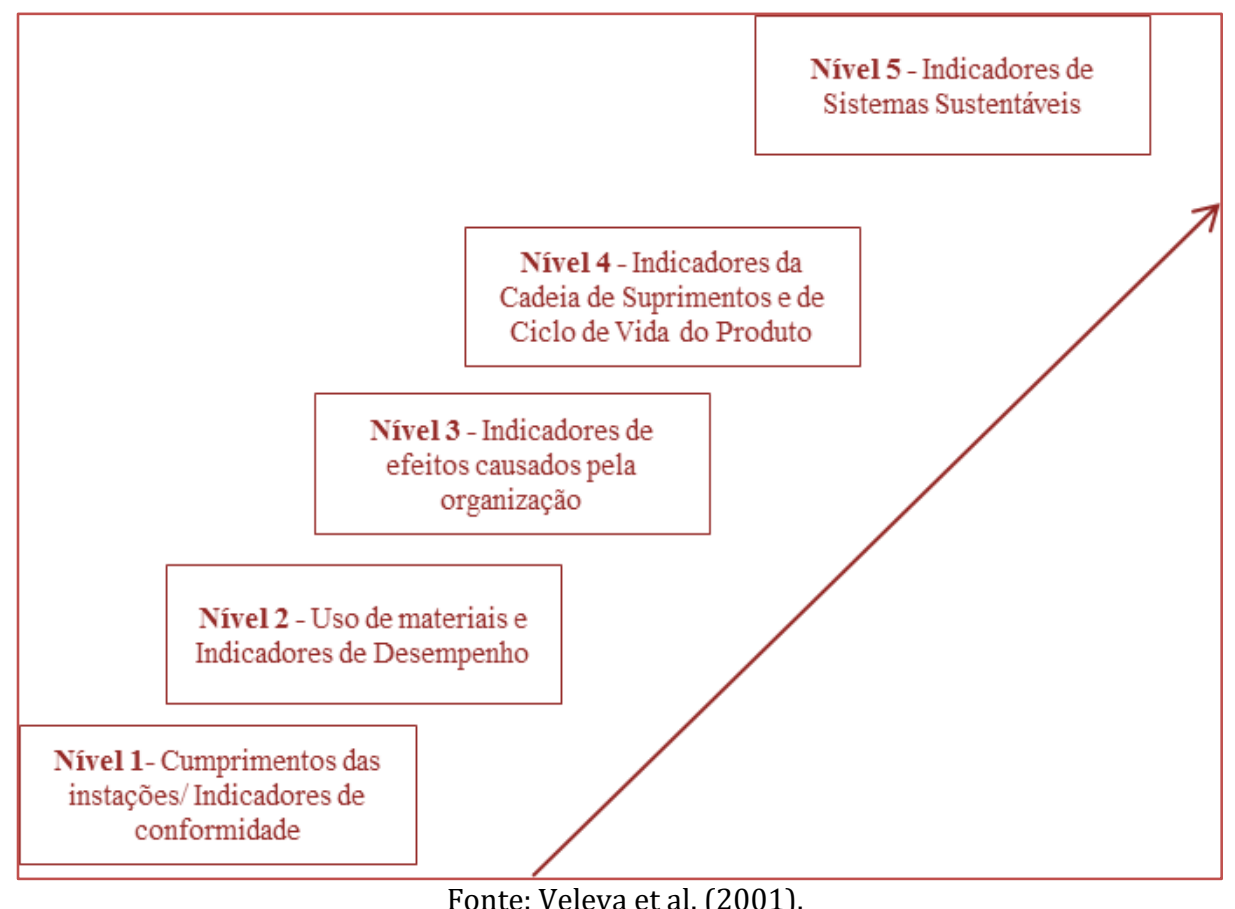

Os estudos de Yunlong e Smit (1994), apontaram que a produção agropecuária pode ser caracterizada como um conjunto de processos interligados nos três pilares da sustentabilidade: econômico, social e ambiental, como pode ser observado na Figura 3. 
Figura 4 - Os três diferentes níveis de sustentabilidade

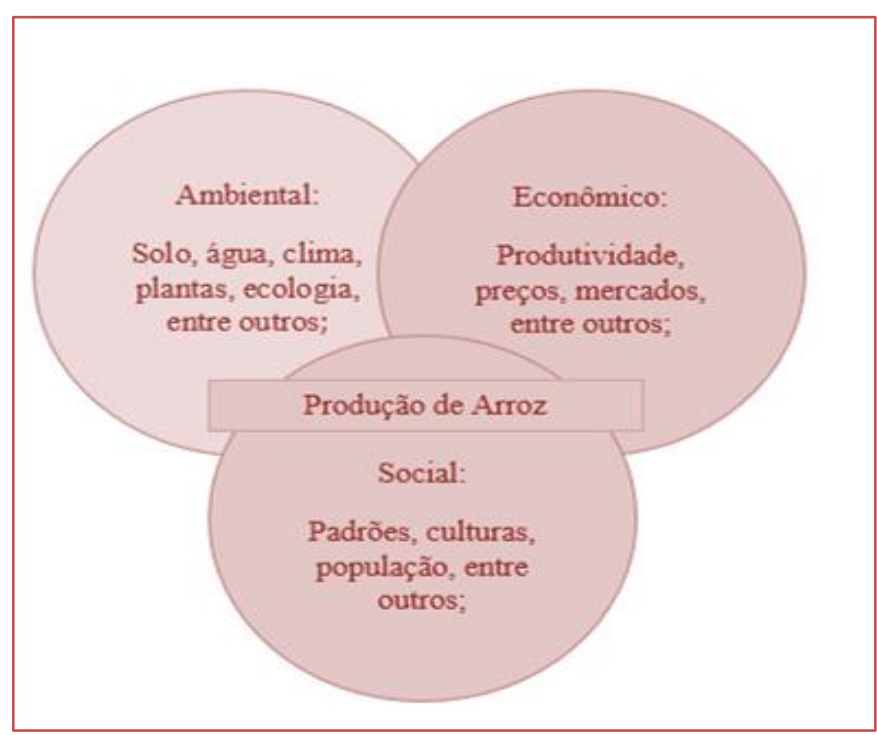

Fonte: Yunlong \& Smit (1994), adaptado pelos autores.

Destarte, Yunlong \& Smit (1994) indicam que pode ser arriscado apontar apenas em uma das dimensões (econômico, ambiental ou social) deve haver o acompanhamento do desenvolvimento da atividade rural nesses três aspectos conjuntos, mesmo havendo a possibilidade de analisar cada um deles separadamente:

[...] sistemas produtivos agrícolas que visam apenas manter a qualidade ambiental, mas não podem produzir um suprimento adequado de comida ou prover retornos econômicos suficientes aos produtores não podem ser enquadrados como sustentáveis. Semelhantemente, sistemas agrícolas que mantém níveis relativamente elevados de produção, mas utilizam quantidades elevadas de insumos para compensar os impactos ambientais da produção podem ser vistos como pouco sustentáveis. (BRKLAICH; BRYANT; SMIT, 1991 apud YUNLONG; SMIT, 1994, p. 304)

\subsection{A PRODUÇÃO DE ARROZ NO BRASIL E MUNDO}

0 arroz, nos últimos cinco anos, aproximadamente, mais de 160 milhões de hectares foram cultivados por safra mundialmente, destaca-se que $75 \%$ de toda área cultivada adota o sistema irrigado, com uma produção de mais de 700 milhões de toneladas de arroz em casca (USDA, 2017). Após, o milho e o trigo, o arroz é a terceira maior cultura cerealífera mundial (WANDER; SILVA, 2014).

Na Figura 5, o Brasil está entre os dez maiores produtores de arroz mundialmente, perdendo apenas para os países asiáticos. Entretanto, na última década com dados disponíveis (2005-2014), o continente asiático configurou $90,5 \%$ da produção mundial de arroz. Destarte, neste mesmo período, o Brasil representou $1,6 \%$ da produção mundial e $52,5 \%$ da produção do continente americano (FAO, 2016). 
Figura 5 - Os maiores países produtores de arroz período de 2010 a 2016

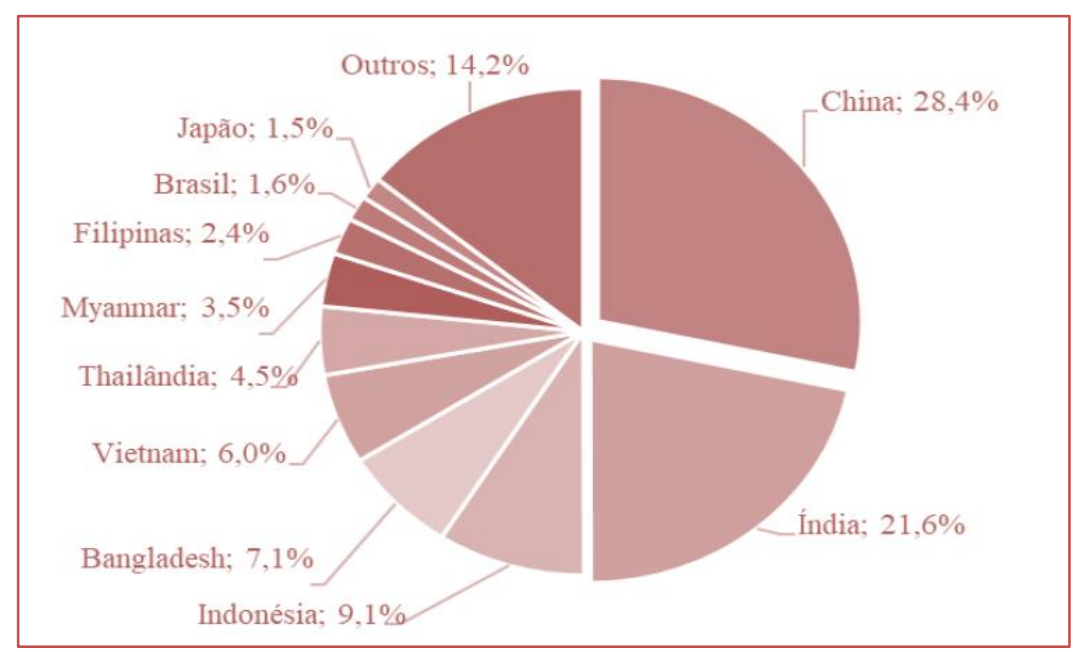

Fonte: Adaptado de dados da FAO e da USDA (IRRI, 2017).

No mercado internacional, segundo dados do United States Department of Agriculture (USDA), a produção mundial de arroz base beneficiado ficará acima dos 488,54 milhões de toneladas na Safra 2017/18 (USDA, 2018). Os países integrantes do Mercosul deverão produzir, na safra 2017/18, o total de 14,9 milhões toneladas de arroz em casca sendo o Brasil responsável por $77,1 \%$ da produção do bloco. Estima-se que a Argentina e Uruguai, somarão cada um por volta de 1,2 milhões de toneladas. Ressalta-se que estes países, na série histórica da balança comercial brasileira representaram relevância em mercados exportadores, suprindo, os déficits no Brasil, entre a oferta e a demanda interna.

Representado na Figura 6, a maior área cultivada e produção se concentra em poucos estados brasileiros, tais como: Rio Grande do Sul e Santa Catarina. O estado do Rio Grande do Sul, representa 69,03\% do arroz produzido na safra 2017/18 (CONAB, 2018). Ainda na Figura 3, é possível observar as maiores produtividades (kg/ha), considerando a média da safra anterior (2016/17), são verificadas nos estados do Rio Grande do Sul $(7.293 \mathrm{~kg} / \mathrm{ha})$ e Santa Catarina $(7.587 \mathrm{~kg} / \mathrm{ha})$. Dentre os estados que produzem arroz, Piauí apresentou a menor produtividade $(1.509 \mathrm{~kg} / \mathrm{ha})$ entre os dados observados.

Figura 6 - Estados brasileiros produtores de arroz

\begin{tabular}{|c|c|c|c|c|c|c|c|c|c|}
\hline \multirow{2}{*}{ RegiajauF } & \multicolumn{3}{|c|}{ Area (em mil ha) } & \multicolumn{3}{|c|}{ Produtividade (em kg/ha) } & \multicolumn{3}{|c|}{ Produçăo (em mil t) } \\
\hline & $\begin{array}{l}\text { Safra } 16 / 17 \\
\text { (a) }\end{array}$ & $\begin{array}{l}\text { Safra } 17 / 18 \\
\text { (b) }\end{array}$ & $\begin{array}{c}\text { VAR \% } \\
\text { (b/a) }\end{array}$ & $\begin{array}{l}\text { Safra } 16 / 17 \\
\text { (c) }\end{array}$ & $\begin{array}{l}\text { Safra } 17 / 18 \\
\text { (d) }\end{array}$ & $\begin{array}{l}\text { VAR \% } \\
\text { (d/c) }\end{array}$ & $\begin{array}{c}\text { Safra } 16 / 17 \\
(\odot)\end{array}$ & $\begin{array}{c}\text { Safra 17/18 } \\
\text { (t) }\end{array}$ & $\begin{array}{c}\text { VAR \% } \\
\text { (e/f) }\end{array}$ \\
\hline Norte & 263,0 & 255,6 & $(2,8)$ & 4.129 & 4.239 & 2,7 & $1.085,8$ & $1.083,3$ & $(0,2)$ \\
\hline RR & 12,3 & 12,3 & - & 7.077 & 7.100 & 0,3 & 87,0 & 87,3 & 0,3 \\
\hline RO & 40,6 & 38,4 & $(5,4)$ & 2.956 & 3.243 & 9,7 & 120,0 & 124,5 & 3,8 \\
\hline PA & 68,8 & 63,4 & $(7,8)$ & 2.728 & 2.694 & $(1,3)$ & 187,7 & 170,8 & $(9,0)$ \\
\hline To & 132,3 & 133,5 & 0,9 & 5.115 & 5.157 & 0,8 & 676,7 & 688,4 & 1,7 \\
\hline Nordeste & 229,2 & 251,7 & 9,8 & 1.908 & 1.860 & $(2,5)$ & 437,3 & 468,2 & 7,1 \\
\hline MA & 141,6 & 164,0 & 15,8 & 1.807 & 1.799 & $(0,4)$ & 255,9 & 295,1 & 15,3 \\
\hline PI & 65,2 & 66,1 & 1,4 & 1.629 & 1.509 & $(7,4)$ & 106,2 & 99,8 & $(6,0)$ \\
\hline AL & 2,8 & 2,8 & - & 6.220 & 5.796 & $(6,8)$ & 17,4 & 16,2 & $(6,9)$ \\
\hline SE & 4,7 & 4,7 & - & 7.540 & 7.128 & $(5,5)$ & 35,4 & 33,5 & $(5,4)$ \\
\hline Centro-Oeste & 189,4 & 179,5 & $(10,0)$ & 3.672 & 3.704 & 0,9 & 732,3 & 665,0 & $(0,2)$ \\
\hline MT & 162,3 & 143,6 & $(11,5)$ & 3.266 & 3.292 & 0,8 & 530,0 & 472,8 & $(10,8)$ \\
\hline MS & 15,5 & 14,3 & $(7,7)$ & 6.000 & 5.900 & $(1,7)$ & 93,0 & 84,4 & $(9,2)$ \\
\hline GO & 21,6 & 21,6 & - & 5.059 & 4.990 & $(1,4)$ & 109,3 & 107,8 & $(1,4)$ \\
\hline Sudeste & 16,1 & 14,3 & $(11,2)$ & 3.389 & 3.646 & 7,3 & 54,7 & 52,1 & $(4,8)$ \\
\hline MG & 6,0 & 4,8 & $(20,0)$ & 2.534 & 2.791 & 10,2 & 15,2 & 13,4 & $(11,8)$ \\
\hline SP & 9,7 & 9,1 & $(6,2)$ & 3.935 & 4.101 & 4,2 & 38,2 & 37,3 & $(2,4)$ \\
\hline Sul & $1.273,2$ & $1.248,1$ & $(2,0)$ & 7.868 & 7.304 & $(7,2)$ & $10.017,7$ & $9.116,1$ & $(9,0)$ \\
\hline PR & 25,1 & 23,8 & $(5,2)$ & 6.506 & 6.058 & $(6,9)$ & 163,3 & 144,2 & $(11,7)$ \\
\hline sc & 147,4 & 146,7 & $(0,5)$ & 7.638 & 7.587 & $(0,7)$ & $1.125,8$ & $1.113,0$ & $(1,1)$ \\
\hline RS & $1.100,7$ & $1.077,6$ & $(2,1)$ & 7.930 & 7.293 & $(8,0)$ & $8.728,6$ & $7.858,9$ & $(10,0)$ \\
\hline Norte/Nordeste & 492,2 & 507,3 & 3,1 & 3.095 & 3.059 & $(1,2)$ & $1.523,1$ & $1.551,5$ & 1,9 \\
\hline Centro-Sul & $1.488,7$ & $1.441,9$ & $(3,1)$ & 7.258 & 6.820 & $(6,0)$ & $10.804,7$ & $9.833,2$ & $(9,0)$ \\
\hline Brasil & $1.980,9$ & $1.949,2$ & $(1,6)$ & 6.223 & 5.841 & $(6,1)$ & $12.32 \pi, 8$ & $11.384,7$ & $(7,7)$ \\
\hline
\end{tabular}

Fonte: CONAB, 2018. 
A Companhia Nacional de Abastecimento - Conab (2016), enfatiza que a cultura do arroz no Brasil possui dois perfil de produção, o sistema irrigado e a de terras altas (anteriormente conhecido arroz de sequeiro). Na década de 1970, o arroz de grão longo produzido em sistema sequeiro era a preferência dos consumidores brasileiros. No entanto, os produtores de arroz irrigado com muita astúcia e esperteza despertaram a preferência pelo arroz longo fino por meio de inovação de cultivares com melhorias de práticas agrícolas e processos tecnológicos transferindo qualidade aos grãos. Dessa forma, aumentando a produtividade do arroz irrigado.

Destarte, no mesmo período a produtividade do arroz de terras altas desenvolveu-se, quando comparado ao arroz irrigado. 0 êxito de mercado pelo arroz irrigado atribui-se a legislação da qualidade de grãos, incentivo governamental de linhas de crédito e cadeia produtiva sincronizada (FERREIRA; MORAIS, 2017). Predomina o cultivo irrigado com $58 \%$ da área cultivada e $86 \%$ da produção total (BORÉM; RANGEL, 2015).

\section{2 AGRONEGÓCIO E A CADEIA PRODUTIVA DE ARROZ NO BRASIL}

As questões da modernização e o aumento significativo das pressões competitivas fazem com que as empresas redefinem suas estratégias para prosseguirem nesse mercado. Dessa forma, os Sistemas Agroindustriais são tidos como "um conjunto de relações contratuais entre empresas e agentes especializados" (ZYLBERSZTAJN, 2000, p. 13), afirmando que as abordagens de Sistemas Agroindustriais (SAGs) podem ser instrumentos indutores do desenvolvimento local.

A presença de diversos produtores de micro e pequenas empresas que agem nos procedimentos produtivos e que interagem com demais outros agentes envolvidos (produtores, clientes, fornecedores, instituições de ensino, governos, bancos, associações e outros) se torna imprescindível o desenvolvimento de coordenação, denominando-se governança. Por meio das características das transações, considera-se a especificidade dos ativos e a incerteza (o risco associado à transação), identificando a forma de governança para o sistema (WILLIANSOM, 1993, 1996; BROUSSEAU, 1993b; ZYLBERSZTAJN, 1995, 2000).

E a Filière que consiste na cadeia de produção que perfaz a análise nas etapas iniciais do produto. E os principais agentes envolvidos são: Indústria de transformação, que são constituídas por empresas que realizam o processamento dos produtos da produção rural (frigoríficos de abate e processamento de bovinos, peixes, suínos e aves, entre outras); atacado, responsável pelos elos entre a indústria de transformação e o varejo (contato direto com o consumidor final) ou consumidor final (direcionador de tendências por meio de escolhas a cadeia de produção pode adotar medidas estratégicas).

Figura 7 - Sistemas Agribusiness

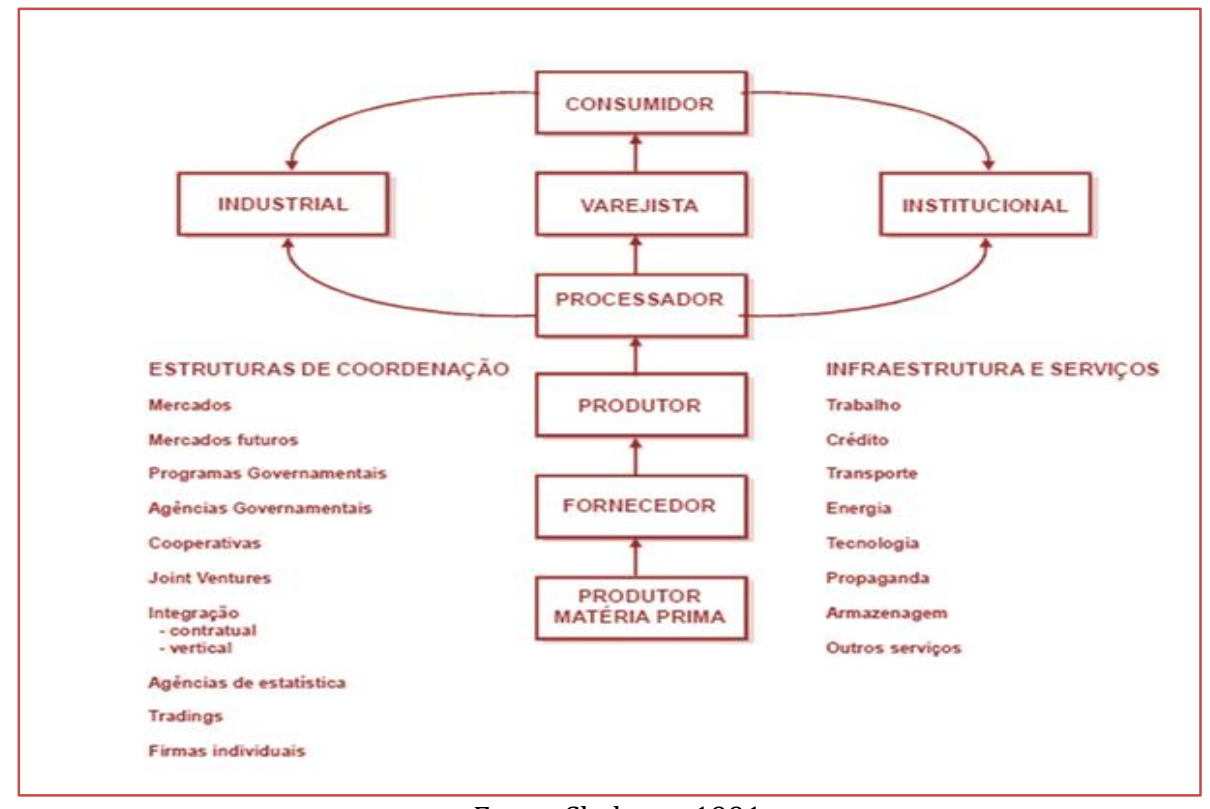


Segundo Morvan (1985, apud ZYLBERSZTAJN, 2000, p. 9), conceitua como:

Cadeia (filiére) é uma seqüência de operações que conduzem à produção de bens. Sua articulação é amplamente influenciada pela fronteira de possibilidades ditadas pela tecnologia e é definida pelas estratégias dos agentes que buscam a maximização dos seus lucros. As relações entre os agentes são de interdependência ou complementaridade e são determinadas por forças hierárquicas. Em diferentes níveis de análise a cadeia é um sistema, mais ou menos capaz de assegurar sua própria transformação.

Ressalva-se a relevância do ambiente institucional e das organizações de suporte ao funcionamento da cadeia. O papel das instituições e os aspectos contratuais são caracterizados como mecanismos de coordenação dos Sistemas Agroindustriais. De acordo com Farina \& Zylbersztajn (1998) as estratégias e a competitividade dependem de fatores, como: o ambiente institucional, o ambiente organizacional e o ambiente tecnológico. Sobre o ambiente institucional ou organizacional Saes (2000), Farina e Zylbersztajn (1994), Zylbersztajn (2003) preconizam o papel das instituições e organizações como contribuir com a provisão de bens públicos, contribuir para valer as regras de jogo informal ou formal, mudanças na alocação de recursos, resolução de conflitos, entre outros fatores. 0 ambiente institucional engloba 0 aparato legal, tradições, culturas e costumes, no entanto, o ambiente organizacional situa-se as associações, informações, pesquisa, finanças, cooperativas, firmas. E o ambiente tecnológico se relaciona ao desenvolvimento de novas tecnologias e os seus impactos para as cadeias de produção.

Nesta perspectiva, ao considerar o ambiente institucional, North (1990) destaca que as regras formais e restrições informais são importantes para definir a interação entre os agentes econômicos. De acordo com o autor, as incertezas decorrentes da racionalidade limitada e do conflito de interesse entre as partes elevam os custos de transação nas relações econômicos. Esses custos são decorrentes da necessidade de garantia das informações para direitos de propriedade, envolvendo mensuração, monitoramento e enforcement (NORTH, 1990).

De forma sucinta, na Figura 8 demonstra o sistema da cadeia produtiva de arroz mediante os conceito de "antes da porteira", "dentro da porteira" e "depois da porteira", criada por Araújo (2005 apud ZAMBERLAN, WAQUIL e HENKIN, 2012).

Figura 8: cadeia produtiva de arroz resumidamente

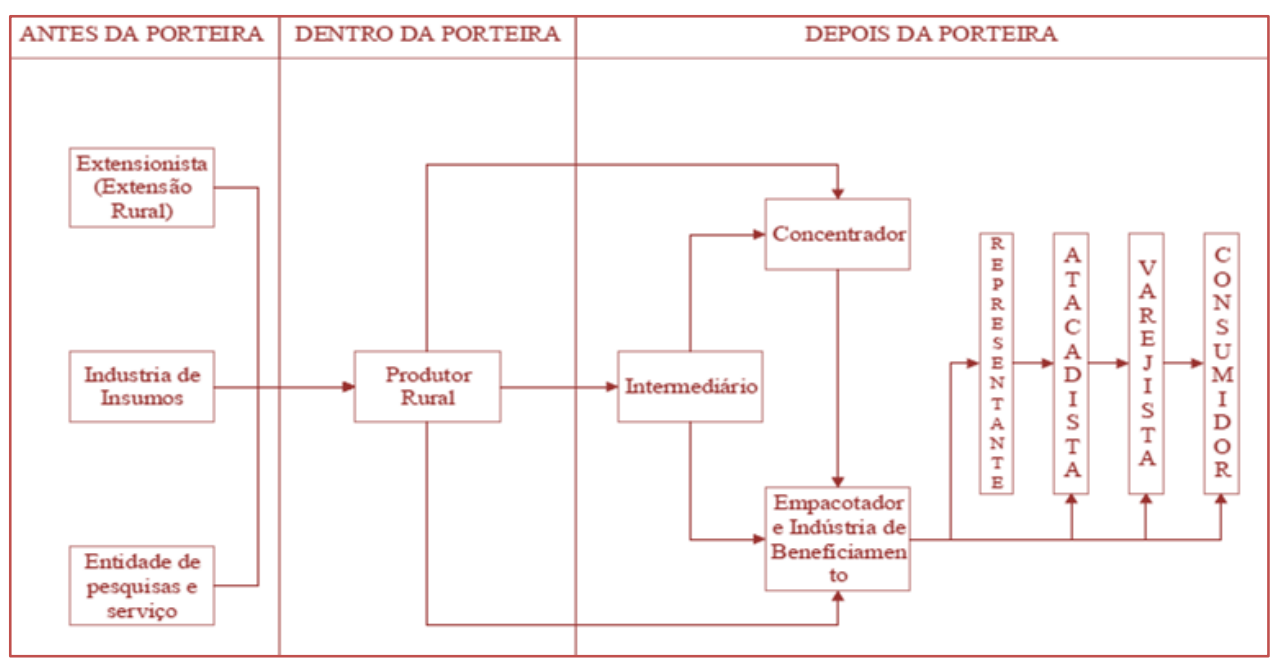

Fonte: Adaptado de Zamberlan, Waquil e Henkin (2012).

Na Figura 8 analisada sob a óptica do agricultor, que localiza "dentro da porteira", oportuna três formas de negociar sua produção: com o intermediário, com o concentrador, sendo assim, as cooperativas que possuem os silos para secagem e a armazenagem do arroz, ou com as indústrias de beneficiamento de arroz. Dentre as alternativas o produtor rural escolhe as estratégias priorizando as que possuem maior retorno financeiro. 


\subsection{A CULTURA DO ARROZ}

A produção de arroz irrigado interfere no meio ambiente negativamente, com a emissão de gases de efeito estufa e poluição da água (BOUMAN ET AL., 2007). No início de 1980, estudos que mensuraram gases com efeito de estufa estimou-se que as lavouras de arroz irrigado emitiam em torno de 50-100t de metano por ano, ou seja, $10-20 \%$ das emissões mundiais de metano (Kirk, 2004). A contaminação das águas subterrâneas podem ocorrer a partir dos biocidas e os seus resíduos (BOUMAN ET AL 2002; BURESH; DATTA 1990). Nas Filipinas, a poluição por nitrato nas águas subterrâneas em sistemas de cultura à base de arroz ultrapassou a margem de $10 \mathrm{mg} \mathrm{L}-1$ para água potável apenas quando altamente vegetais fertilizados foram incluídos no sistema de cultivo (BOUMAN ET AL 2002).

A preparação da terra é a base para toda a época de colheita, assim como, uma boa gestão da água são canais de campo, terraplanagem e operações de lavoura (BOUMAN ET AL., 2007). A construção de canais secundários para transportar agua melhora grandemente o controle individual e essa prática é recomendada em qualquer tipo de sistema de irrigação. Um campo bem nivelado é um pré-requisito para uma boa cultivar. Quando os campos não são de nível, a água pode estagnar em depressões, enquanto partes mais altas pode tornar-se seca. Isso desencadeia na emergência desigual colheita e crescimento inicial irregular, distribuição de adubo irregular, e problemas com plantas daninhas (BOUMAN ET AL., 2007).

Figura 9 - Sistematização do plantio do arroz

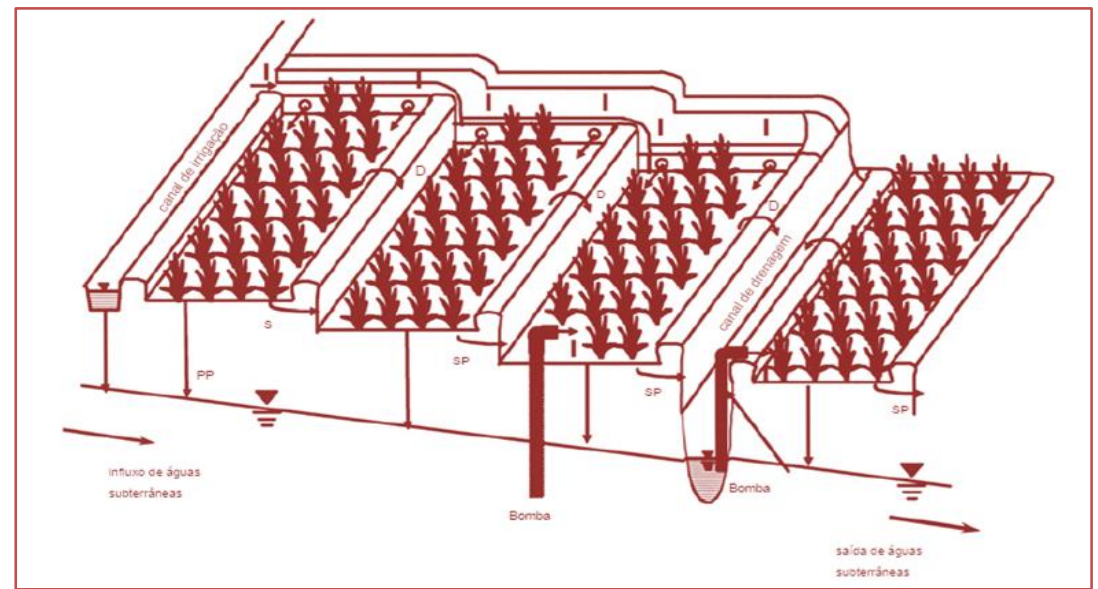

Água superficial e sub superficial flui através de uma sequência de campos de arroz. D = drenagem (fluxo overbund), I = irrigação, $\mathrm{P}=$ percolação, $\mathrm{S}$ = infiltração

Fonte: BOUMAN ET AL., 2007.

No entanto, os agricultores podem usar pequenas bombas para levantar a água para irrigar os campos que são distribuídos por canais de irrigação (BOUMAN ET AL., 2007). Estudos recentes de sistemas de irrigação à base de arroz na China e nas Filipinas indicam que muitos indicadores de desempenho água (tais como produtividade da água, fração de água aplicada usado pela cultura) melhorar com o aumento da escala espacial por causa da reutilização da água (HAFEEZ, 2003; LOEVE ET AL, 2004). Grande parte dessa reutilização é feito informalmente pelos agricultores que tomam iniciativa própria para bombear água, bloquear canais de drenagem, ou construir pequenos reservatórios na exploração para o armazenamento secundário (BOUMAN ET AL., 2007). 


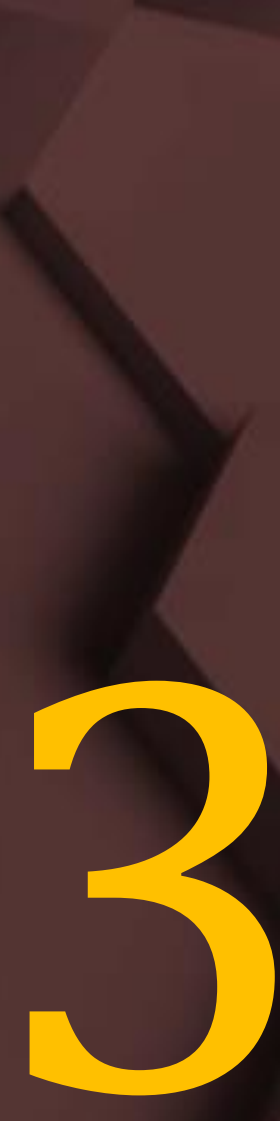

Procedimentos

Metodológicos 


\section{PROCEDIMENTOS METODOLÓGICOS}

Neste capítulo se apresenta o método utilizado para alcançar os objetivos desta pesquisa. Entende-se por procedimentos metodológicos a caracterização do caminho que foi utilizado para responder à questão de pesquisa proposta. Para isso, foi levantado referencial teórico relacionado à análise da sustentabilidade no agronegócio, especificamente na produção de arroz.

Conforme já exposto, este trabalho analisa a sustentabilidade das propriedades rurais produtoras de arroz no pantanal sul-mato-grossense tomando por base aos principais indicadores de sustentabilidade encontrados na literatura. E, com isso, identifica características tecnológicas, estruturais e gerenciais que expliquem as diferenças do desempenho sustentável das operações entre elas.

\subsection{CARACTERIZAÇÃO DA ÁREA DE ESTUDO}

O estado de Mato Grosso do Sul é uma das 27 unidades federativas do Brasil. Localiza-se no sul da Região Centro-Oeste faz divisa com os estados: Mato Grosso (norte), Goiás e Minas Gerais (nordeste), São Paulo (leste) e Paraná(sudeste); e dois países sul-americanos: Paraguai (sul e sudoeste) e Bolívia (oeste). Sua área é de 357 145,532 km², com uma população de 2619657 habitantes em 2014, Mato Grosso do Sul é o 21ํo estado mais populoso do Brasil (IBGE, 2018).

Na safra 2017/2018, segundo dados do Levantamento Sistemático de Produção Agrícola LSPA - julho (2018), a área cultivada de arroz foi de 15.342 hectares, o Brasil produziu 11.538.069t de arroz, e deste total, o Mato Grosso do Sul correspondeu por 98.992t, ou seja, 0,86\% do total produzido nacional (IBGE, 2018), com uma produtividade média de $6.452 \mathrm{~kg} / \mathrm{ha}$ (IBGE, 2018). Entre os municípios produtores de arroz em Mato Grosso do Sul, destaca-se: Miranda e Rio Brilhante, que juntos representam $61 \%$ de toda produção estadual (IBGE, 2017).

Figura 10- Localização da área em estudo. Área do município de Miranda - MS e Rio Brilhante - MS, destacada em cinza.

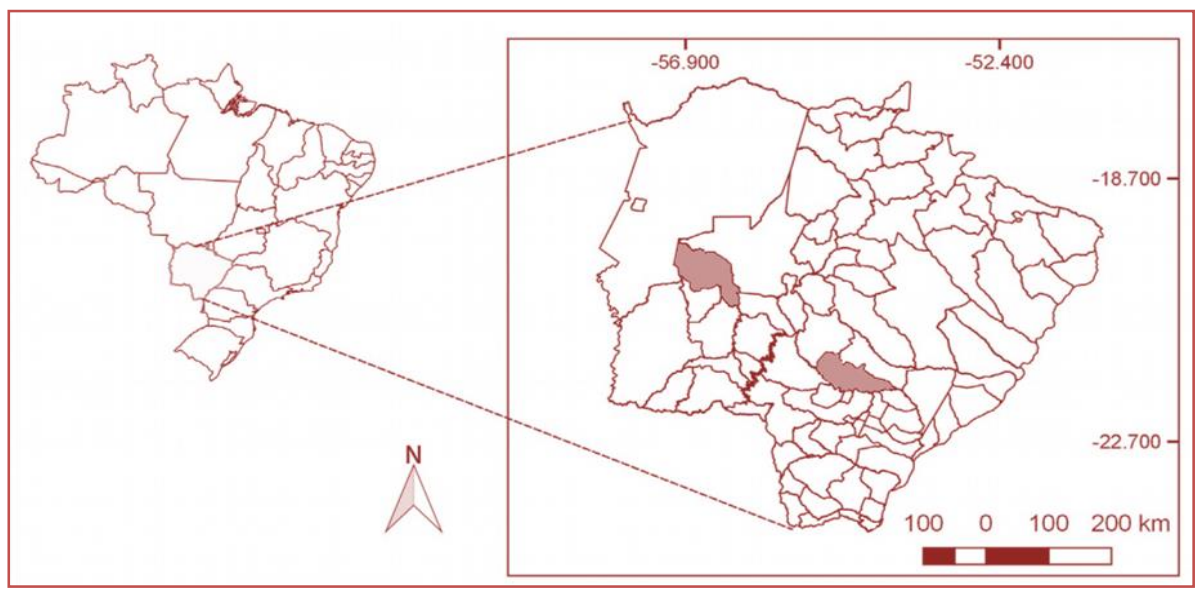

Fonte: Dados da pesquisa, 2018.

\subsection{OBTENCÃO DE VALORES DE INDICADORES}

Diferentes métodos tem sido empregados para obtenção dos valores de sub índices na avaliação de indicadores. Segundo Nardo et al. (2006), a escolha do método ou técnica apropriada será embasada nos dados com finalidade de desenvolver índice. No entanto, Ebert \& Welsch (2004) advertem em relação aos diferentes métodos ocasionam resultados distintos.

a) Método de classificação

Consiste numa técnica simples, em função da relevância comparativa entre os indicadores onde são dispostos em ordem crescente ou decrescente. A equação para este método: 


$$
S_{i}=\operatorname{Rank}\left(X_{i}\right)(1)
$$

Onde, Si representa o valor do indicador $i$; e $X i$ corresponde ao valor real do indicador $i$; Dessa forma, são apresentados os rankings e as informações referente a cada indicador cada vez menos significativo (NARDO ET AL., 2006). Essa técnica foi adotada na aplicação do Índice de Tecnologia (TAI) para compor os valores de indicadores (CHERCHYE ET AL., 2007).

\section{b) Redimensionamento contínuo}

É utilizado para obter uma gama de valores de indicadores de forma idêntica, atribuindo notas de $0-1$ ou de $0-10$, em que 0 é o valor mínimo ou critico; e 1 ou 10, o valor máximo ou desejado do indicador. A equação geral para calcular os valores de indicadores utilizando este método:

$$
S_{i}=\frac{X_{i}-X_{\min }}{X_{\max }-X_{\min }} \times 100(2)
$$

Em que, Si configura o valor do indicador $i ; X_{i}$ corresponde ao valor atual do indicador $i ; X_{\min }$ e $X_{\max }$ são os limites mínimo e máximo do indicador. Essa técnica foi abordado para Água Índice de Pobreza (LAWRENCE ET AL., 2003), Índice de Desenvolvimento Humano (RODRÍGUEZ, 2011) e Índice de sustentabilidade da Água (JUWANA ET AL., 2011).

\section{c) Distância em relação à referência}

0 método consiste na escolha de uma referência que pode ser regional, nacional ou internacional, considerando um determinado lugar e certo período de tempo, como a disponibilidade de dados de séries temporais para os indicadores (NARDO ET AL., 2006). A equação geral para este método é:

$$
S_{i}=\frac{X_{i}}{X_{t}}(3)
$$

Onde, Si representa o valor do indicador $i$; $X_{i}$ corresponde ao valor do indicador no período e $X_{t}$, representa o valor real do indicador no tempo. Esse procedimento foi utilizado na aplicação do índice de mercado interno (NARDO ET AL., 2006).

\section{d) Escala categórica}

Este método consiste em atribuir categorias para o indicador baseado em alguns critérios definidos que podem ser quantitativas (valores como 1-5) ou qualitativas (como "muito bom", "bom" ou "ruim"). A equação geral para este método é:

$$
\begin{gathered}
Z_{j} \text { if } X_{i} \text { meets criteria } 1 \\
Z_{j} \text { if } X_{i} \text { meets criteria } 1 \\
S_{i}= \\
\ldots \ldots \\
Z_{j} \text { if } X_{n} \text { meets criteria } n
\end{gathered}
$$

Onde, Si é o valor do indicador $i$; $X_{i}$ é o valor real do indicador $i ; Z_{j}$ é a categoria para $X_{i}$ atender aos critérios $j$, e $n$ é o número de categorias. Destarte, a adoção deste método para obter índices dos três 
indicadores, Divulgação de Informação, Estrutura de Governança e Aplicação da Lei (JUWANA ET AL., 2011).

\subsection{PONDERAÇÃO DE PESOS}

De acordo com Nardo et al. (2005) classifica-se os pesos aos indicadores pela ponderação em duas categorias, as técnicas estatísticas e os métodos à base de participação. São exemplos da abordagem de ponderação estatística, análise fatorial, análise dos componentes principais, entre outras (HARVEY \& KOOPMAN, 2000; NARDO ET AL., 2005). E na abordagem à base de participação, métodos tais como Alocação Budget (BAL), e Analytic Hierarchy Process (AHP), utilizada na tomada de decisão no atendimento ao cliente (KWONG \& BAI, 2002), desenho operacional (MACHARIS ET AL., 2004) e na conservação da água (Zhang, 2009).

\subsection{CÁLCULO DOS PESOS DOS INDICADORES}

O AHP consiste num processo analítico para tomada de decisões, chamado "The analytic hierarchy process" técnica proposta por Saaty (1987), para a atribuição de pesos de critérios quando apreciação qualitativa de especialistas ou público em geral foi envolvida. E a construção das matrizes de comparação paritária adota a seguinte escala:

Tabela 1- Método AHP

\begin{tabular}{|c|l|}
\hline \multicolumn{2}{|c|}{ Escala numérica } \\
\hline 1 & Ambos elementos são de igual importância \\
\hline 3 & Moderada importância de um elemento sobre outro \\
\hline 5 & Forte importância de um sobre o outro \\
\hline 7 & Importância muito forte de um elemento sobre o outro \\
\hline 9 & Extrema importância de um elemento sobre o outro \\
\hline $2,4,6,8$ & Valores intermediários entre as relações adjacentes \\
\hline
\end{tabular}

Fonte: Saaty, 1990.

A comparação dos indicadores representa-se por uma matriz quadrada e recíproca para cada dimensão.

$$
A=\left[\begin{array}{ccc}
a_{1,1} & a_{1,2} & a_{1, n} \\
a_{2,1} & a_{2,2} & a_{2, n} \\
a_{n} & a_{n 2} & a_{n}
\end{array}\right](5)
$$

Onde, aij representa a importância relativa do atributo da linha $i$ em relação ao atributo $j$; seu recíproco (1/aij) é expressa no lado oposto da diagonal principal.

Para a normalização das matrizes de julgamento, divide-se cada valor da matriz pelo respectivo somatório da coluna. Consequentemente, obtêm se uma nova matriz com os dados normalizados, onde o valor médio de cada linha da matriz representa o peso do respectivo indicador.

O auto valor máximo ( $\lambda$ max $)$ do vetor de ponderação calcula-se pela seguinte equação:

$$
\lambda_{\max }=\frac{1}{n} \times\left(\frac{W_{1}^{\prime}}{W_{1}}+\frac{W_{\prime 2}}{W_{2}}+\frac{W_{\prime} n}{W_{n}}\right)(6)
$$


Onde, [W'] representa o vetor de ordem n, contendo os elementos ponderados. 0 método AHP, propõe uma análise da razão de consistência (CR) que é a lógica dos dados, visto que a matriz é obtida por julgamentos pessoais. O RC é dado pela equação:

$$
R C=\left[\frac{C I}{R I}\right] \times 100
$$

Onde RI é a razão de inconsistência aleatória obtido para uma matriz recíproca de ordem n:

Tabela 2- Índice de inconsistência

\begin{tabular}{|c|c|c|c|c|c|c|c|c|c|c|c|}
$\begin{array}{c}\text { Dimensão da } \\
\text { matriz }\end{array}$ & 1 & 2 & 3 & 4 & \multicolumn{2}{|c|}{5} & 6 & 7 & 8 & 9 & 10 \\
\hline $\begin{array}{c}\text { Inconsistência } \\
\text { aleatória }\end{array}$ & 0 & 0 & 0,58 & 0,9 & 1,12 & 1,24 & 1,32 & 1,41 & 1,42 & 1,49 \\
\hline
\end{tabular}

Fonte: Saaty, 1991.

O índice de consistência (IC) é dado por:

$$
C I=\frac{\lambda_{\max }-n}{(n-1)}(8)
$$

Onde, $\lambda_{\max }$ é o maior autovalor da matriz de julgamentos. Para cada linha da matriz de comparação determina-se a soma ponderada, baseando na soma do produto de cada valor da mesma pelo peso do respectivo indicador; após os resultados obtidos deverão ser divididos pelos pesos do indicador da respectiva linha matriz gerando uma média de cada linha, obtendo $\lambda_{\max }$.

Dessa forma, os dados são considerados consistentes segundo Saaty (1980) RC =0,10 e até 0,20 é considerado como não afetar drasticamente Karlsson, 1998 citados por OCDE (2008), os pesos.

\subsection{AGREGAÇÃO}

Na composição de um índices e sub-índices, os valores dos indicadores são agregados para obter os valores de componentes e o valor final do índice. No entanto, a média aritmética e métodos geométricos é frequentemente utilizado para agregar sub-índices de vários índices. 0 método aritmético é abordado em diversos estudos (CHAVES; ALIPAZ, 2007; POLICY RESEARCH INITIATIVE, 2007, JUWANA ET AL., 2012), consiste na soma dos valores de sub-índice ponderado (NARDO ET AL., 2005). É dado pela seguinte equação:

$$
I=\sum_{i=1}^{N} w_{i} S_{i}(9)
$$

Onde, $I$ corresponde o índice agregado, $N$ é o número de indicadores para ser agregado, $S_{i}$ é o sub-índice para o indicador $i$ e wi é o peso do indicador $i$.

O método de agregação geométrico considera as diferenças nos valores de sub-índice na agregação de indicadores, entretanto, o método de agregação aritmética não considera essas diferenças. Portanto, se a diferença de valores de sub-índice é importante, o método geométrico é mais apropriado (JUWANA ET AL., 2012). É dado pela seguinte equação: 


$$
\prod_{i=1}^{N} S_{i}^{w i}
$$

Os símbolos da equação (10) são os mesmos que os da equação (9). No entanto, ambas equações podem ser usadas em diferentes níveis de agregação (JUWANA ET AL., 2012). 


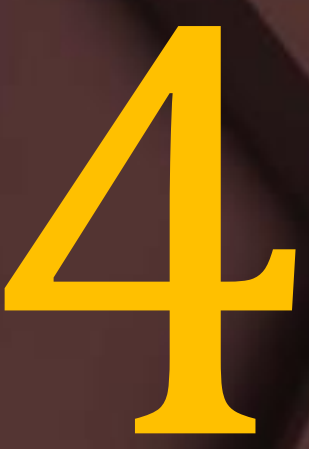

\section{Discussão e}

Apresentação dos

dados 


\section{DISCUSSÃO E APRESENTAÇÃO DOS DADOS}

Como apresentado em capítulos anteriores, a metodologia empregada por "The analytic hierarchy process" técnica proposta por Saaty (1987), serviu como base para a avaliação do desempenho sustentável das operações da produção de arroz em fazendas localizadas no estado de Mato Grosso do Sul, este capítulo está agregado ao capítulo anterior, onde é apresentado todo o memorial de cálculos dos indicadores de sustentabilidade.

Desta maneira, para a estimativa destes indicadores nas propriedades rurais produtoras de arroz em Mato Grosso do Sul foram utilizados fatores de emissão/conversão e constantes mais adequadas à realidade local sempre que possível.

\subsection{COMPOSIÇÃO DOS ÍNDICES DOS INDICADORES}

Os indicadores têm a finalidade de elementos de síntese, sendo considerados parâmetros representativos, simples e de fácil interpretação, empregados para explicitar as características principais do objeto de estudo.

A seleção de indicadores para a construção do método procedeu-se na revisão da literatura sobre a agricultura e sobre fatores, mecanismos estressores e impactos negativos causados, por um sistema de produção de arroz. E ainda o consenso dos especialistas físicas e sociais, profissionais ligados ao setor, pesquisadores e outros interessados (LAWRENCE ET AL., 2003). No entanto, a definição de fortalezas e debilidades para cada indicador foram definidos de acordo com a revisão literária e as legislações internacional, nacional e regional (TABELA 3).

Tabela 3- Composição de Indicadores

\begin{tabular}{|c|c|c|c|c|}
\hline Dimensão & Indicadores & Sub-indicadores & Parâmetros & \\
\hline & & & Unidade & Máx Min \\
\hline Ambiental & $\begin{array}{l}\text { Reduzir o estresse da } \\
\text { Água }\end{array}$ & $\begin{array}{c}\text { Consumo de } \\
\text { fertilizantes por } \\
\text { hectare de terra } \\
\text { arável }\end{array}$ & Kg/Hectares & \\
\hline & & $\begin{array}{l}\text { Consumo de } \\
\text { agrotóxicos por } \\
\text { hectare de terra } \\
\text { arável }\end{array}$ & $\mathrm{Kg} /$ Hectares & \\
\hline & Biodiversidade & $\begin{array}{c}\text { Espécies ameaçadas } \\
\text { de aves }\end{array}$ & $\begin{array}{c}0,25,75 \text { e } 100 \text { (escala categórica foi } \\
\text { usada) }\end{array}$ & \\
\hline & & $\begin{array}{l}\text { Espécies ameaçadas } \\
\text { de mamíferos }\end{array}$ & $\begin{array}{c}\text { 0, 25, } 75 \text { e } 100 \text { (escala categórica foi } \\
\text { usada) }\end{array}$ & \\
\hline & & $\begin{array}{l}\text { Espécies ameaçadas } \\
\text { de anfíbios }\end{array}$ & $\begin{array}{c}0,25,75 \text { e } 100 \text { (escala categórica foi } \\
\text { usada) }\end{array}$ & \\
\hline & & $\begin{array}{l}\text { Desmatamento e } \\
\text { corte de vegetação }\end{array}$ & $\begin{array}{c}0,25,75 \text { e } 100 \text { (escala categórica foi } \\
\text { usada) }\end{array}$ & \\
\hline & Resíduos sólidos & & $\begin{array}{c}\text { 0, 25, } 75 \text { e } 100 \text { (escala categórica foi } \\
\text { usada) }\end{array}$ & \\
\hline & $\begin{array}{l}\text { Equipamento de } \\
\text { Proteção Individual }\end{array}$ & & $\begin{array}{c}0,25,75 \text { e } 100 \text { (escala categórica foi } \\
\text { usada) }\end{array}$ & \\
\hline & $\begin{array}{l}\text { Qualidade da água } \\
\text { físico-químicos e } \\
\text { biológicos }\end{array}$ & & $\mu / L$ & $0,5-0,1$ \\
\hline & Governança ambiental & $\begin{array}{l}\text { Área de reserva } \\
\text { legal }\end{array}$ & $\begin{array}{c}0,25,75 \text { e } 100 \text { (escala categórica foi } \\
\text { usada) }\end{array}$ & \\
\hline
\end{tabular}


Tabela 3- Composição de Indicadores

(continuação...)

\begin{tabular}{|c|c|c|c|c|}
\hline \multirow[t]{2}{*}{ Dimensão } & \multirow[t]{2}{*}{ Indicadores } & Sub-indicadores & Parâmetros & \\
\hline & & $\begin{array}{l}\text { Área de Preservação } \\
\text { Permanente }\end{array}$ & $\begin{array}{c}0,25,75 \text { e } 100 \text { (escala categórica foi } \\
\text { usada) }\end{array}$ & \\
\hline & Eco-Eficiência & Consumo de água & $\mathrm{m}^{3} / \mathrm{ha}$ & $\begin{array}{l}1.500- \\
1.300\end{array}$ \\
\hline & Terra & $\begin{array}{l}\text { Zoneamento } \\
\text { agroclimático }\end{array}$ & $\begin{array}{c}0,25,75 \text { e } 100 \text { (escala categórica foi } \\
\text { usada) }\end{array}$ & \\
\hline & & Análise do solo & $\begin{array}{c}0,25,75 \text { e } 100 \text { (escala categórica foi } \\
\text { usada) }\end{array}$ & \\
\hline & & Rotação de culturas & $\begin{array}{c}0,25,75 \text { e } 100 \text { (escala categórica foi } \\
\text { usada) }\end{array}$ & \\
\hline & & $\begin{array}{l}\text { Matéria orgânica do } \\
\text { solo }\end{array}$ & $\begin{array}{c}0,25,75 \text { e } 100 \text { (escala categórica foi } \\
\text { usada) }\end{array}$ & \\
\hline \multirow[t]{6}{*}{ Econômica } & Produtividade/hectares & & toneladas/hectares & $\begin{array}{c}6.223- \\
5.109\end{array}$ \\
\hline & Comercialização & & $\begin{array}{c}0,25,75 \text { e } 100 \text { (escala categórica foi } \\
\text { usada) }\end{array}$ & \\
\hline & $\begin{array}{l}\text { Situação perante } \\
\text { agentes financeiros }\end{array}$ & & $\begin{array}{c}0,25,75 \text { e } 100 \text { (escala categórica foi } \\
\text { usada) }\end{array}$ & \\
\hline & $\begin{array}{l}\text { Dependência de } \\
\text { recursos externos }\end{array}$ & & & $\begin{array}{l}4.324,96- \\
2.567,70^{*}\end{array}$ \\
\hline & Margem bruta & & & $\begin{array}{c}2.198,32- \\
986,38^{*}\end{array}$ \\
\hline & $\begin{array}{l}\text { Sincronia com as } \\
\text { tendências } \\
\text { contemporâneas }\end{array}$ & & $\begin{array}{c}0,25,75 \text { e } 100 \text { (escala categórica foi } \\
\text { usada) }\end{array}$ & \\
\hline \multirow[t]{6}{*}{ Social } & Nível educacional & & $\begin{array}{c}0,25,75 \text { e } 100 \text { (escala categórica foi } \\
\text { usada) }\end{array}$ & \\
\hline & Métodos participativos & $\begin{array}{l}\text { Participação em } \\
\text { organizações }\end{array}$ & $\begin{array}{c}0,25,75 \text { e } 100 \text { (escala categórica foi } \\
\text { usada) }\end{array}$ & \\
\hline & & $\begin{array}{c}\text { Participação em } \\
\text { cursos de } \\
\text { capacitação }\end{array}$ & $\begin{array}{c}0,25,75 \text { e } 100 \text { (escala categórica foi } \\
\text { usada) }\end{array}$ & \\
\hline & $\begin{array}{l}\text { Estrutura da } \\
\text { comunidade }\end{array}$ & $\begin{array}{c}\text { Valorização e } \\
\text { manutenção da } \\
\text { paisagem natural }\end{array}$ & $\begin{array}{c}0,25,75 \text { e } 100 \text { (escala categórica foi } \\
\text { usada) }\end{array}$ & \\
\hline & & $\begin{array}{l}\text { Reconhecimento } \\
\text { dos valores e } \\
\text { tradições locais }\end{array}$ & $\begin{array}{c}0,25,75 \text { e } 100 \text { (escala categórica foi } \\
\text { usada) }\end{array}$ & \\
\hline & Emprego/Renda & & $\begin{array}{c}0,25,75 \text { e } 100 \text { (escala categórica foi } \\
\text { usada) }\end{array}$ & \\
\hline
\end{tabular}

Fonte: Dados da Pesquisa, 2018.

Os indicadores de dimensão ambiental foram catalogados conforme Esty et al., 2005, considerou 8 indicadores e cada um constitui entre 1 e 3 conjuntos de dados de sub-indicadores para um total de 13 variáveis subjacentes. Para obter os valores de variáveis adotou o redimensionamento continuo (equação 2) e os valores máximos e mínimos utilizados os valores mais altos e mais baixos reais de estudos na área. Além da escala categórica (equação 4). 
Reduzir o estresse da Água, por exemplo, é um indicador composto que inclui as variáveis consumo de fertilizantes por hectare de terra arável e consumo de agrotóxicos por hectare de terra arável, para obter os valores dos parâmetros utiliza escala categórica (eq. 2). Para Bado et al. (2018), os agricultores da África Sub- Sariana (SAA), utilizam fertilizantes como forma de aumentar a produtividade; no entanto, os agricultores de SAA utilizam apenas 5-9 Kg hectares-1 (ha) de fertilizante, e Yanggen et al. (1998), apontam que na América Latina e Ásia aplica-se 50 e $80 \mathrm{~kg}$ ha-1. Em sistemas tradicionais de arroz, uso de pesticidas em arroz irrigado varia de 0,4 kg ingredientes ha-1 em Tamil Nadu, Índia, para 3,8 kg ha-1 na província de Zhejiang, China (BOUMAN ET AL 2002).

Para Esty (2005), a biodiversidade relaciona-se com o desenvolvimento da atividade agrícola pode afetar os recursos naturais como a fauna, espécies de aves, anfíbios e mamíferos; e a flora desmatamento e corte da vegetação (equação 4).

Os resíduos sólidos correspondem a destinação adequada das embalagens de defensivos agrícolas (herbicidas, fungicidas, adubos e inseticidas) e materiais advindos dos maquinários e equipamentos, tais como: lubrificantes, óleos e solventes decorrentes da utilização destes no abastecimento e manutenção de equipamentos e na limpeza de estruturas e ferramentas (SRIVASTAVA, 2007; MAZZA ET AL., 2016), adotou a equação 4 .

No que se refere ao uso de Equipamento de Proteção Individual, condiz com o vestuário envolvido no manuseio de agrotóxicos, material ou equipamento para a proteção da pessoa na produção, manipulação e uso de agrotóxicos, seus componentes e afins, que constitui obrigatoriedade com base no Decreto no 4074/2002 (BRASIL,2002), utilizou a equação (4) com as categorias "Preferencial", "Tolerada" e Inapta".

A qualidade da agua associa-se a contaminação dos ecossistemas aquáticos por liberação de efluentes de todos produtos químicos destinados a proteção do cultivo, como herbicidas, pesticidas, fungicidas e entre outros (SETHUNATHAN; SIDDARAMAPPA, 1978; CUI ET AL., 2000; BOUMAN ET AL., 2002; BOUMAN ET AL., 2007). A legislação da Comunidade Econômica Europeia - CEE (estabelece que o resíduo máximo seja de $0,1 \mu$ /L para qualquer agrotóxico isoladamente e de $0,5 \mu / \mathrm{L}$ para o total dos agroquímicos presentes em amostras de água destinadas ao consumo humano (DEFRA, 2008), observadas na equação 2. Corroborando, em estudos nas Filipinas as concentrações de resíduos de biocidas nas águas sob o cultivo irrigado estabeleceu entre $0,1 \mu / \mathrm{L}$ e $0,5 \mu / \mathrm{L}$ para consumo de água com segurança (BOUMAN ET AL., 2002).

A governança ambiental é a maneira de assegurar os riscos e oportunidades relacionados com a sustentabilidade, sendo identificados e geridos baseando-se num código de conduta pessoal priorizando a auto-regulação. Quanto a reserva legal, adotou a Lei ${ }^{\circ}$ 12.651/2012 (BRASIL, 2012), que estabelece a obrigatoriedade de averbação de área de reserva legal, Eq. (4). A "Área de Preservação Permanente" é uma área protegida, coberta ou não por vegetação nativa, com finalidade de preservar os recursos hídricos, a paisagem, a estabilidade geológica e a biodiversidade, Lei nº4.771/1965 (BRASIL,1965), corresponde a preservação, a exploração e a recuperação (equação 4).

A eco-efienciencia aborda um modelo produtivo com menos consumo de agua e energia para obter a mesma quantidade da produção (ESTY, 2005). O consumo de água pelo arroz $\left(\mathrm{m}^{3} / \mathrm{ha}\right)$ baseou-se na transpiração, a evapotranspiração, irrigação, mais precipitação (BOUMAN; TUONG, 2001; TUONG ET AL., 2005). Evapotranspiração típicos de cultivos de arroz são 4-5mm, em período chuvoso e $6-7 \mathrm{~mm}$ em período seco (TABBAL ET AL., 2002). No entanto, cerca de 30-40\%, evapotranspiração é a evaporação (BOUMAN ET AL., 2005; SIMPOSON ET AL., 1992). Aproximadamente 1.300-1.500 mm é o valor típico para o arroz irrigado na Ásia (BOUMAN ET AL., 2007). Os estudos de ZWART \& BASTIAANSSEN (2004) encontraram o valor de 0,6-1 $\mathrm{kg} \mathrm{m}^{3}$, Eq. (2).

O indicador Terra (equação 4) contempla as tecnologias de cultivo e de conservação do solo (ESTAY, 2005; BOUMAN ET AL., 2007).Entre as variáveis está a matéria orgânica, que consiste na capacidade de fornecimento de nutrientes e produtividade no longo prazo (DAWE ET AL., 2000; DITTERT ET AL 2002); a rotação de cultura é necessária sempre que observar falhas em rendimentos, pela presença de pulgões na raízes, fungos e desordens nutricionais (BOUMAN ET AL., 2007), além da adubação verde, rotação de culturas, cultivo mínimo, rompimento de compactação sub superficial, cobertura vegetal (CABANGON; TUONG 2000; SHARMA ET AL., 1995); o zoneamento agroclimático tange as épocas de plantio que minimizam adversidades climáticas, áreas mais indicadas para o plantio e a segurança para obter maiores produtividades (FERREIRA ET AL., 2005b; ARF ET AL., 2000; ZONEAMENTO AGRÍCOLA, 2000).

Os indicadores econômicos foram estabelecidos pelos estudos de van Ittersum (2007), que a produtividade representa a média nacional no período de estudo (2013-2017) valores fornecidos pela 
Companhia Nacional de Abastecimento- CONAB (equação 2). Embasado na Lei Federal de no 8.171/91, a comercialização abrange todo o sistema de produção e as relações comerciais. Considera-se como os principais riscos da dimensão econômica a situação perante agentes financeiros que representa o endividamento do agricultor perante terceiros na Lei Federal citada (equação 4).

Dependência de recursos externos incide sobre o conjunto dos insumos externos, corresponde à média nacional dos custos variáveis entre o período 2013-2017, disponibilizado pela Companhia Nacional de Abastecimento- CONAB. E o índice de margem bruta procedeu da mesma forma que o indicador anterior (Equação 2). 0 índice do indicador Sincronia com as tendências contemporâneas corresponde ao melhoramento do arroz com variedades híbridas com altos rendimentos (YUAN, 2001), estabelecido na equação 4.

Os indicadores sociais foram determinados pela Commission on Sustainable Development (2001), o nível educacional caracteriza o grau acadêmico do produtor de arroz. 0 indicador de métodos participativos fundamentou-se no contexto de Olson (2011) que a teoria da ação coletiva por meio da observação da existência de atitudes típicas de indivíduos utilitaristas, sendo assim, indivíduos que agem por interesse próprio buscando maximizar o interesse pessoal. Aborda dois sub-indicadores: participação em organizações e participação em cursos de capacitação, fundamentou-se no contexto de Olson (2011) que a teoria da ação coletiva por meio da observação da existência de atitudes típicas de indivíduos utilitaristas, sendo assim, indivíduos que agem por interesse próprio buscando maximizar o interesse pessoal.

A composição do indicador da estrutura da comunidade envolve dois sub-indicadores (equação 4): i) valorização e manutenção da paisagem natural e; o ii) reconhecimento dos valores e tradições locais. As festas tradicionais e práticas religiosas estão interligadas ao cultivo de arroz e os campos são valorizados por sua beleza deslumbrante (BOUMAN ET AL., 2007). E o emprego/renda ancorados no serviço culturais de arroz são extremamente valorizados em países asiáticos, onde o arroz constitui mais importante fonte de emprego e renda (BOUMAN ET AL., 2007).

\subsection{MENSURAÇÃO DOS INDICADORES DE SUSTENTABILIDADE}

Considerando um período de cinco anos (2013-2017) para a análise da sustentabilidade da produção de arroz em MS, os dados socioeconômicos para a mensuração dos indicadores neste trabalho foram obtidos no Diagnóstico realizado no período 2013/2017 pela Associação de Produtores Irrigantes de Mato Grosso do Sul - APAI, que presta serviços de assistência técnica e extensão rural, aos produtores de arroz no estado de Mato Grosso do Sul.

A finalidade do diagnóstico foi a descrição e análise da realidade socioeconômica como instrumento básico para a elaboração da caracterização da cadeia produtiva do arroz em Mato Grosso do Sul. A metodologia adotada para a coleta de dados que constam no diagnóstico foi a combinação de várias técnicas, tais como a entrevista semiestruturada, reuniões e a observação direta ou participando de reuniões e diálogos com produtores, representantes de organizações sociais e políticos da região.

No entanto, constam no diagnóstico informações sobre a situação atual dos produtores, processo de comercialização da produção, questões ambientais e econômicas, entre outras. Com base no referido diagnóstico, foi possível mensurar 16 dos 18 indicadores selecionados, pois, o diagnóstico não contém informações sobre os outros dois indicadores: produtividade e qualidade de água.

Destarte, as informações que não constavam no diagnóstico foram novamente solicitadas por via e-mail a APAI. Entretanto, a APAI, enviou as informações que contêm os dados da produtividade do MS das safras 2013/14, 2014/15, 2015/16, 2016/17 e 2017/18, correspondentes ao período do presente estudo.

A produtividade média obtida foi calculada pela média aritmética das produtividades das safras 2013/14, 2014/15, 2015/16, 2016/17 e 2017/18, nas riziculturas de estudo. Considerou-se a média de produtividade do estado de Mato Grosso do Sul de cinco safras acompanhadas pela Companhia Nacional de Abastecimento - CONAB, no estado de Mato Grosso do Sul (equação 3).

Tabela 4 - Produtividade

\begin{tabular}{|c|c|c|c|c|c|}
\multicolumn{1}{c}{ Safra } & $2013 / 14$ & $2014 / 15$ & $2015 / 16$ & $2016 / 17$ & $2017 / 18$ \\
\hline Produtividade & 6.150 & 6.160 & 4.860 & 6.000 & 5.700 \\
\hline
\end{tabular}

Fonte: Dados da pesquisa, 2018. 
Para o indicador qualidade de água optou-se por fazer uso dos dados disponíveis pelo Instituto de Meio Ambiente de Mato Grosso do Sul- IMASUL (2018) que estabelece os parâmetros para cursos d'água de classe 2 (TABELA 5), de acordo com a Resolução do Conselho Nacional do Meio Ambiente (CONAMA), de 357/2005 e a Deliberação do Conselho Estadual de Controle Ambiental (CECA), 36/2012. Destarte, o Índice de Qualidade da Água) desenvolvido pela National Sanitation Foundation Institution destaca-se por reunir em um único valor diversos parâmetros: temperatura, $\mathrm{pH}$, oxigênio dissolvido, demanda bioquímica de oxigênio, coliformes termotolerantes, nitrogênio total, fósforo total, sólidos totais e turbidez. 0 monitoramento dos parâmetros de qualidade da água foi realizado na UPG Miranda, que são as fontes hídricas que alimentam as riziculturas. Para avaliar o possível impacto da cultura do arroz sobre a qualidade das águas as amostras para análise e cálculo do IQA foram coletadas no período março de 2017dezembro de 2017, correspondentes aos períodos seco e chuvoso (equação 2).

Tabela 5 - Qualidade da água

\begin{tabular}{|c|c|c|c|c|c|c|}
\hline Parâmetro & Unidade & $\begin{array}{c}\text { ** PADRÕES } \\
\text { CONAMA 357/05 } \\
\text { e CECA-MS 36/12 }\end{array}$ & Mar. & Jun. & Set. & Dez. \\
\hline Temperatura da água & ${ }^{\circ} \mathrm{C}$ & - & 28 & 25 & 25 & 27 \\
\hline $\mathrm{pH}$ & - & 6,0 a 9,0 & 7,6 & 7,8 & 7,9 & 7,5 \\
\hline OD & $\mathrm{mg} / \mathrm{L}$ & $\geq 6$ & 7,20 & 7,4 & 7,5 & 6,8 \\
\hline DBO $(5,20)$ & $\mathrm{mg} / \mathrm{L}$ & 3 & 2 & $<3$ & 11 & $<3$ \\
\hline Coli. Termotolerantes & $\mathrm{NMP} / 100 \mathrm{ml}$ & 200 & 790 & 490 & 130 & 5.400 \\
\hline Nitrogênio total & $\mathrm{mg} / \mathrm{L}$ & - & 0,69 & 0,30 & 0,30 & 0,92 \\
\hline Fósforo total & $\mathrm{mg} / \mathrm{L}$ & 0,1 & 0,087 & $<0,100$ & $<0,100$ & 0,295 \\
\hline Sólidos totais & $\mathrm{mg} / \mathrm{L}$ & - & 177 & 113 & 110 & 189 \\
\hline Turbidez & UNT & 40 & 460 & 16,3 & 10,6 & 73,6 \\
\hline
\end{tabular}

Fonte: Adaptado de CONAMA 357/05 e CECA-MS 36/12

A avaliação dos resultados da análise de água da saída da lavoura é o referencial para estabelecer notas, baseada nos seguintes critérios: i) Quando os valores das análises da água de irrigação na saída da lavoura estão melhores que na entrada, considera-se como resultado positivo (não reduz nota do indicador); ii) Quando todos os valores das análises estão dentro dos níveis estabelecidos pelo CEE, considera-se normalmente os resultados situados abaixo do 3 o quartil (75\% dos valores), Eq. (4). O IQA possui média zero e variância unitária, estando compreendido entre -3 e 3 , denotando os valores negativos como os de melhor qualidade (TOLEDO et al., 2002).

Para a maioria dos indicadores (18) mensurados com base no Diagnóstico e apresentados em porcentagens, foi aplicada a escala categórica. Os critérios de diagnóstico para a definição de fortalezas e debilidades dos indicadores foram definidos com base na revisão da literatura e na legislação brasileira associada a percepção dos pesquisadores (equação 4).

\subsection{PONDERAÇÃO}

Para Sullivan et al. (2006) enfatiza a responsabilidade na determinação de pesos indicador deve ser atribuída aos tomadores de decisão, e não aos investigadores. Dessa forma, realizou a construção das matrizes de comparação paritária entre os indicadores abordando a escala de Saaty (1987).

A escolha dos especialistas teve como critérios profissionais atuantes no setor de arroz, tais como: Companhia Nacional de Abastecimento- CONAB, IRGA e EPAGRI. A comparação dos indicadores no método AHP foi realizada por profissionais de cada área nas dimensões ambiental, econômica e social. No totalizaram-se doze especialistas sendo quatro para cada dimensão. Os participantes tinham entre 23 e 57 anos e visitaram diferentes áreas com cultivo de arroz tanto no âmbito nacional e internacional. A comparação dos indicadores foi representada por uma matriz quadrada e reciproca para cada dimensão 
(TABELA 6). A ferramenta foi aplicada aos especialistas por meio de planilhas desenvolvidas em ambiente Microsoft Excel. Os questionários foram tabulados para que fosse possível calcular a média aritmética de todas as respostas dos especialistas (equação 9).

Tabela 6- Método AHP Dimensão Ambiental

\begin{tabular}{|c|c|c|c|c|c|c|c|c|c|c|c|}
\hline Indicadores & $\mathrm{RA}$ & $\mathrm{BIO}$ & $\mathrm{RS}$ & EPI & IQA & $\mathrm{GA}$ & $\mathrm{ECOE}$ & $\mathrm{T}$ & $\begin{array}{l}\text { Auto } \\
\text { Vetor }\end{array}$ & $\begin{array}{l}\text { Auto } \\
\text { Vetor } \\
\text { Normal } \\
\text { izado }\end{array}$ & $\begin{array}{l}\text { Desvio } \\
\text { Padrão }\end{array}$ \\
\hline $\begin{array}{l}\text { Reduzir o estresse da } \\
\text { água (RA) }\end{array}$ & 1 & 3 & 3 & 3 & 5 & 3 & 2 & 2 & 2,5188 & $27 \%$ & 1,5871 \\
\hline Biodiversidade( $\mathrm{BIO}$ ) & 0,33 & 1 & 2 & 5 & 2 & 5 & 3 & 2 & 1,9392 & $21 \%$ & 1,3926 \\
\hline Resíduos Sólidos (RS) & 0,33 & 0,5 & 1 & 3 & 2 & 3 & 2 & 2 & 1,3643 & $15 \%$ & 1,1680 \\
\hline $\begin{array}{l}\text { Equipamento de } \\
\text { proteção } \\
\text { individual(EPI) }\end{array}$ & 0,33 & 0,2 & 0,33 & 1 & 2 & 3 & 2 & 2 & 0,9244 & $10 \%$ & 0,9615 \\
\hline $\begin{array}{l}\text { Qualidade da água } \\
\text { físico-químicos e } \\
\text { biológicos(IQA) }\end{array}$ & 0,20 & 0,5 & 0,5 & 0,5 & 1 & 3 & 3 & 2 & 0,9050 & $10 \%$ & 0,9513 \\
\hline $\begin{array}{l}\text { Governança } \\
\text { ambiental(GA) }\end{array}$ & 0,33 & 0,2 & 0,33 & 0,33 & 0,33 & 1 & 3 & 3 & 0,6214 & $7 \%$ & 0,7883 \\
\hline Eco Eficiência(ECOE) & 0,50 & 0,33 & 0,5 & 0,5 & 0,5 & 0,33 & 1 & 2 & 0,5859 & $6 \%$ & 0,7654 \\
\hline Terra(T) & 0,50 & 0,50 & 0,5 & 0,5 & 0,5 & 0,33 & 0,5 & 1 & 0,5183 & $6 \%$ & 0,7199 \\
\hline$\Sigma$ & 3,53 & 6,23 & 8,17 & 13,83 & 13,33 & 18,67 & 16,50 & 16 & 9,3773 & $100 \%$ & \\
\hline
\end{tabular}

Fonte: Dados da pesquisa, 2018.

Quanto a dimensão ambiental, em relação à matriz de correlação a mesma foram confirmadas pelo $\lambda$-max $(9,229)$, RC $(0,12)$ e IC $(0,175)$, esses resultados confirmaram o justos do modelo à matriz dos dados originais.

Quanto a dimensão econômica, em relação à matriz de correlação a mesma foram confirmadas pelo $\chi$-max $(6,9153), \mathrm{RC}(0,15)$ e IC $(0,183)$, esses resultados confirmaram o justos do modelo à matriz dos dados originais (Tabela 7).

Quanto a dimensão social, em relação à matriz de correlação a mesma foram confirmadas pelo $\chi$-max $(4,1172)$, RC $(0,03)$ e IC $(0,03)$, esses resultados confirmaram o justos do modelo à matriz dos dados originais (Tabela 8 ). 
Tabela 7- Método AHP Dimensão Econômica

\begin{tabular}{|c|c|c|c|c|c|c|c|c|c|}
\hline Indicadores & $\mathrm{P} / \mathrm{H}$ & $\mathrm{COM}$ & SAF & DRE & MB & STC & $\begin{array}{l}\text { Auto } \\
\text { Vetor }\end{array}$ & $\begin{array}{l}\text { Auto Vetor } \\
\text { Normalizado }\end{array}$ & $\begin{array}{l}\text { Desvio } \\
\text { Padrão }\end{array}$ \\
\hline $\begin{array}{l}\text { Produtividade/hectares } \\
\text { (P/H) }\end{array}$ & 1 & 5 & 5 & 3 & 2 & 5 & 3,0142 & $41 \%$ & 1,7362 \\
\hline Comercialização(COM) & 0,2 & 1 & 2 & 3 & 2 & 2 & 1,2988 & $18 \%$ & 1,1396 \\
\hline $\begin{array}{l}\text { Situação perante agentes } \\
\text { financeiros(SAF) }\end{array}$ & 0,2 & 0,5 & 1 & 3 & 5 & 2 & 1,2009 & $16 \%$ & 1,0959 \\
\hline $\begin{array}{l}\text { Dependência de recursos } \\
\text { externos(DRE) }\end{array}$ & 0,33 & 0,33 & 0,33 & 1 & 2 & 2 & 0,7274 & $10 \%$ & 0,8529 \\
\hline Margem bruta(MB) & 0,5 & 0,5 & 0,2 & 0,5 & 1 & 2 & 0,6070 & $8 \%$ & 0,7791 \\
\hline $\begin{array}{l}\text { Sincronia com as } \\
\text { tendencias } \\
\text { contemporaneas(STC) }\end{array}$ & 0,2 & 0,5 & 0,5 & 0,5 & 0,5 & 1 & 0,4817 & $7 \%$ & 0,6941 \\
\hline$\sum$ & 2,43 & 7,83 & 9,03 & 11 & 12,5 & 14 & 7,3301 & $100 \%$ & \\
\hline
\end{tabular}

Fonte: Dados da pesquisa, 2018.

Tabela 8- Método AHP Dimensão Social

\begin{tabular}{|l|c|c|c|c|c|c|c|}
\multicolumn{2}{|c}{ Indicadores } & NE & MP & EC & \multicolumn{2}{c|}{ ER } & \multicolumn{2}{c|}{ Auto Vetor } & $\begin{array}{c}\text { Auto vetor } \\
\text { normalizado }\end{array}$ & Desvio Padrão \\
\hline Nível educacional (NE) & 1 & 3 & 5 & 5 & 2,94283 & $56 \%$ & 1,71547 \\
\hline $\begin{array}{l}\text { Métodos participativos } \\
\text { (MP) }\end{array}$ & 0,33 & 1 & 2 & 3 & 1,18921 & $23 \%$ & 1,09051 \\
\hline $\begin{array}{l}\text { Estrutura da } \\
\text { comunidade (EC) }\end{array}$ & 0,2 & 0,5 & 1 & 3 & 0,74008 & $14 \%$ & 0,86028 \\
\hline Emprego/Renda (ER) & 0,2 & 0,33 & 0,33 & 1 & 0,38610 & $7 \%$ & 0,62137 \\
\hline$\Sigma$ & 1,73 & 4,83 & 8,33 & 12 & 5,25822 & $100 \%$ & \\
\hline
\end{tabular}

Fonte: Dados da pesquisa, 2018. 
Resultados 


\section{RESULTADOS}

Neste capítulo é apresentado o nível de sustentabilidade nas três dimensões (ambiental, econômica e social) dos indicadores das propriedades produtoras de arroz do estado de Mato Grosso do Sul. No decorrer do capítulo é discutido os resultados do desempenho sustentável das fazendas a partir dos indicadores de sustentabilidade calculados. Por fim, é apresentado os resultados da análise descrevendose as principais semelhanças e diferenças do desempenho sustentável.

\subsection{COMPOSIÇÃO DOS NÍVEIS DE SUSTENTABILIDADE}

Os índices de sustentabilidade calculados, considerando a nota e peso de cada indicador foram de 6,04; 8,53 e 6,16, para as dimensões ambiental, econômica e social respectivamente (Tabela 9).

Tabela 9 - Composição dos níveis de sustentabilidade

\begin{tabular}{|c|c|c|c|}
\hline Indicador & Indicador (Nota) & Peso & $\mathrm{IS}=\mathrm{I}^{*} \mathrm{P}$ \\
\hline Reduzir o estresse da Água & 4,98 & 0,27 & 1,34 \\
\hline Biodiversidade & 5,33 & 0,21 & 1,12 \\
\hline Resíduos sólidos & 9,48 & 0,15 & 1,42 \\
\hline Equipamento de Proteção Individual & 7,00 & 0,10 & 0,70 \\
\hline Qualidade da água físico-químicos e biológicos & 6,18 & 0,10 & 0,62 \\
\hline Governança ambiental & 5,86 & 0,07 & 0,41 \\
\hline Eco Eficiência & 4,75 & 0,06 & 0,29 \\
\hline Terra & 2,43 & 0,06 & 0,15 \\
\hline Índice de Sustentabilidade Ambiental & & & 6,04 \\
\hline Produtividade/hectares & 10,00 & 0,41 & 4,10 \\
\hline Comercialização & 8,57 & 0,18 & 1,54 \\
\hline Situação perante agentes financeiros & 7,75 & 0,16 & 1,24 \\
\hline Dependência de recursos externos & 5,89 & 0,10 & 0,59 \\
\hline Margem bruta & 7,23 & 0,08 & 0,58 \\
\hline Sincronia com as tendências contemporâneas & 6,78 & 0,07 & 0,47 \\
\hline Índice de Sustentabilidade econômica & & & 8,53 \\
\hline Nível educacional & 3,78 & 0,56 & 2,12 \\
\hline Métodos participativos & 9,67 & 0,23 & 2,22 \\
\hline Estrutura da comunidade & 8,60 & 0,14 & 1,20 \\
\hline Emprego/Renda & 8,76 & 0,07 & 0,61 \\
\hline Índice de Sustentabilidade Social & & & 6,16 \\
\hline
\end{tabular}

Fonte: Dados da pesquisa, 2018.

A dimensão ambiental apresentou o índice mais baixo entre as dimensões analisadas. 0 indicador que constituiu em grande parte para a baixa sustentabilidade ambiental na rizicultura foi a Terra que apresenta as variáveis zoneamento agroclimático, análise do solo, rotação de culturas e matéria orgânica do solo, pois tem um desempenho 2,43 mas com peso 0,06, que é significativo no cálculo do índice. 0 fato dos produtores não realizarem a análise do solo caracterizou nota baixa e de não realizarem rotação de culturas. Corroborando, o arroz não pode ser cultivado periodicamente no mesmo ambiente a cada ano sem uma redução no rendimento e além de indícios de pragas e doenças transmitidas pelo solo (GEORGE ET AL., 2002; SHARMA ET AL., 2002; VENTURA ET AL., 1981). 
A dimensão ambiental foi caracterizada por oito indicadores (Figura 11), Reduzir o estresse da Água $(1,34)$, Biodiversidade $(1,12)$, Resíduos sólidos $(1,42)$, Equipamento de Proteção Individual $(0,70)$, Qualidade da água físico-químicos e biológicos $(0,62)$, Governança ambiental $(0,41)$, Eco-Eficiência $(0,29)$ e Terra $(0,15)$.

Figura 11- Nível de dimensão ambiental

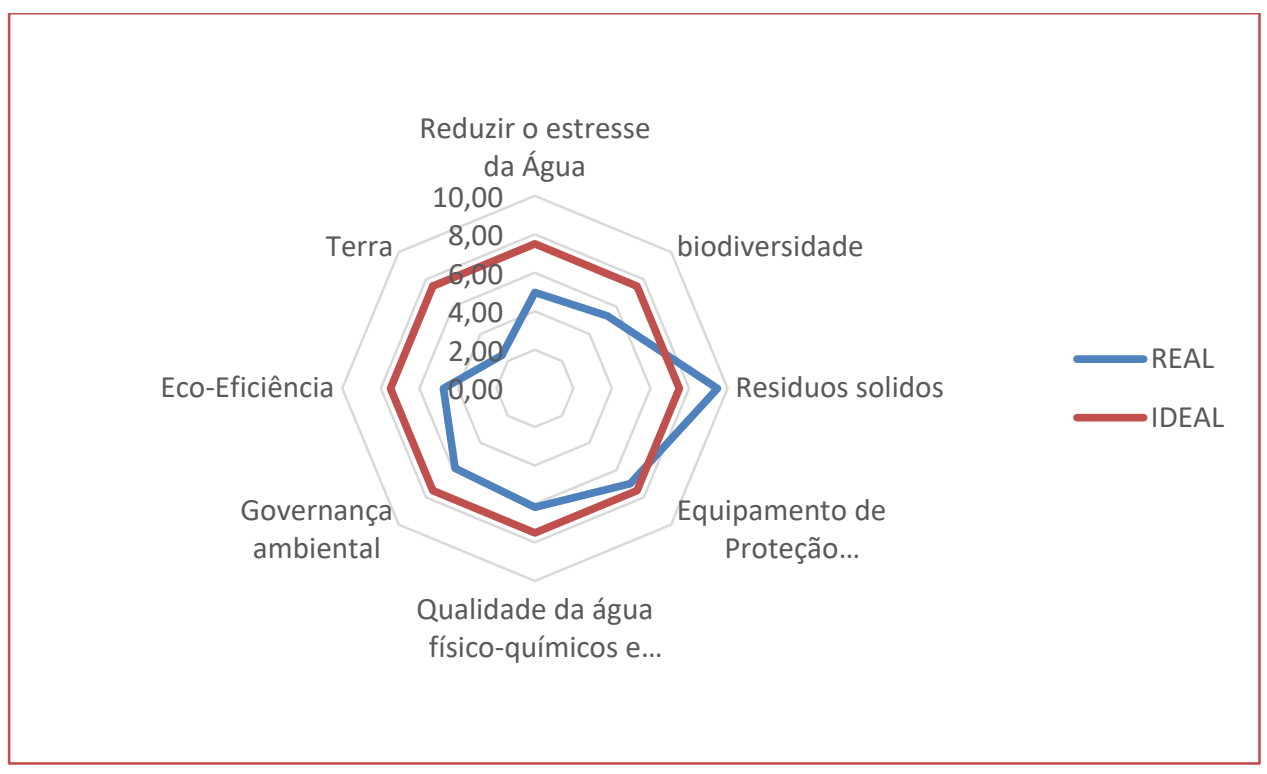

Fonte: Dados da pesquisa, 2018.

0 indicador reduzir o estresse da agua $(1,34)$ está associado com os consumos elevados de fertilizantes $(170 \mathrm{Kg})$ e agrotóxicos, sendo assim, a aplicação de azoto fertilizante $(\mathrm{N})$ em excesso na planta para atingir uma produtividade óptima está relacionado com altos níveis de nitrato residual no solo, o que potencialmente contribuir a água subterrânea e a poluição atmosférica, entre outros (SWIETLIK, D., 1992; RAHMAN; ZHANG, 2018). Já o indicador biodiversidade $(1,12)$ referentes as espécies de aves, mamíferos, anfíbios e desmatamento e corte de vegetação estão correlacionados, consequentemente, por haver desmatamento há um declínio na fauna (ESTY, 2005).

0 indicador "Uso de Equipamento de Proteção Individual" no manuseio de agrotóxicos refere-se ao todo vestuário, material ou equipamento para a proteção da pessoa envolvida na produção, manipulação e uso de agrotóxicos, seus componentes e afins, que constitui obrigatoriedade com base no Decreto no 4074/2002 (BRASIL,2002). Nesse caso, não foi cumprida na totalidade a obrigatoriedade da lei, fazendo com que este indicador obtivesse nota 0,70 .

O desempenho do indicador Governança ambiental $(0,41)$, poderá melhorar nos estudos futuros, em virtude de reflorestamento e recuperação de mata ciliar que estão decorrendo nas regiões das riziculturas.

Outro indicador que contribuiu significativamente para o baixo índice da dimensão ambiental foi o relacionado a Eco-Eficiência $(0,29)$, onde as propriedades pesquisadas consomem em torno de $8.500 \mathrm{~m}^{3}$ de água para o cultivo do arroz irrigado. A quantidade de agua usada para produzir $1 \mathrm{Kg}$ de arroz está na faixa de 500 a $2.000 \mathrm{~m}^{3} \mathrm{~kg}$ se levar em consideração apenas a evapotranspiração (Tuong, 1999). Destarte, o grande desafio do setor agrícola é produzir mais alimentos com menos água (Tuong et al., 2005).

E os resíduos sólidos $(1,42)$, geralmente na zona rural é aplicado agrotóxicos e as embalagens, após o uso continuam contaminadas com resíduos perigosos (MACIEL, QUINTO JUNIOR; OLIVEIRA, 2011). No entanto, $95 \%$ das embalagens foram recolhidas do campo e enviados corretamente no Brasil, fator este a eficácia da logística reversa que envolve todos os membros do segmento, como fabricantes, revenda, agricultores e poder público (Mazza et al., 2016). As políticas e as ações citadas, em especial a lei que trata dos resíduos sólidos, preveem que ações ambientais, sociais e outros investimentos na produção limpa, como os programas de ecoeficiência (SISINNO e MOREIRA, 2005). 
0 indicador Qualidade da água físico-químicos e biológicos $(0,62)$, também influenciaram negativamente o índice da dimensão ambiental, Embora não se tenha analisado a quantidade de resíduos de agrotóxicos no presente estudo, estes podem ter contribuído que o IQA encontrado não estivesse num intervalo ótimo. Um estudo realizado em 2006 pelo Instituto Brasileiro de Geografia e Estatística (IBGE), evidenciou que no Brasil é preocupante a contaminação dos solos e aguas por agrotóxicos e fertilizantes, pois de 5,281 municípios analisados 1.134 (21,5\%) informaram esse problema. 0 uso de agrotóxicos e fertilizantes é a segunda causa de contaminação da agua no pais (VEIGA ET. AL., 2006).

A dimensão econômica é caracterizada por 6 indicadores (Figura 12), Produtividade/hectares $(10,0)$, Comercialização $(8,57)$, Situação perante agente financeiro $(7,75)$, Dependência de recursos externos $(5,89)$, Margem bruta $(7,23)$ e Sincronia com as tendências contemporâneas $(6,78)$.

Figura 12 - Nível de dimensão econômica

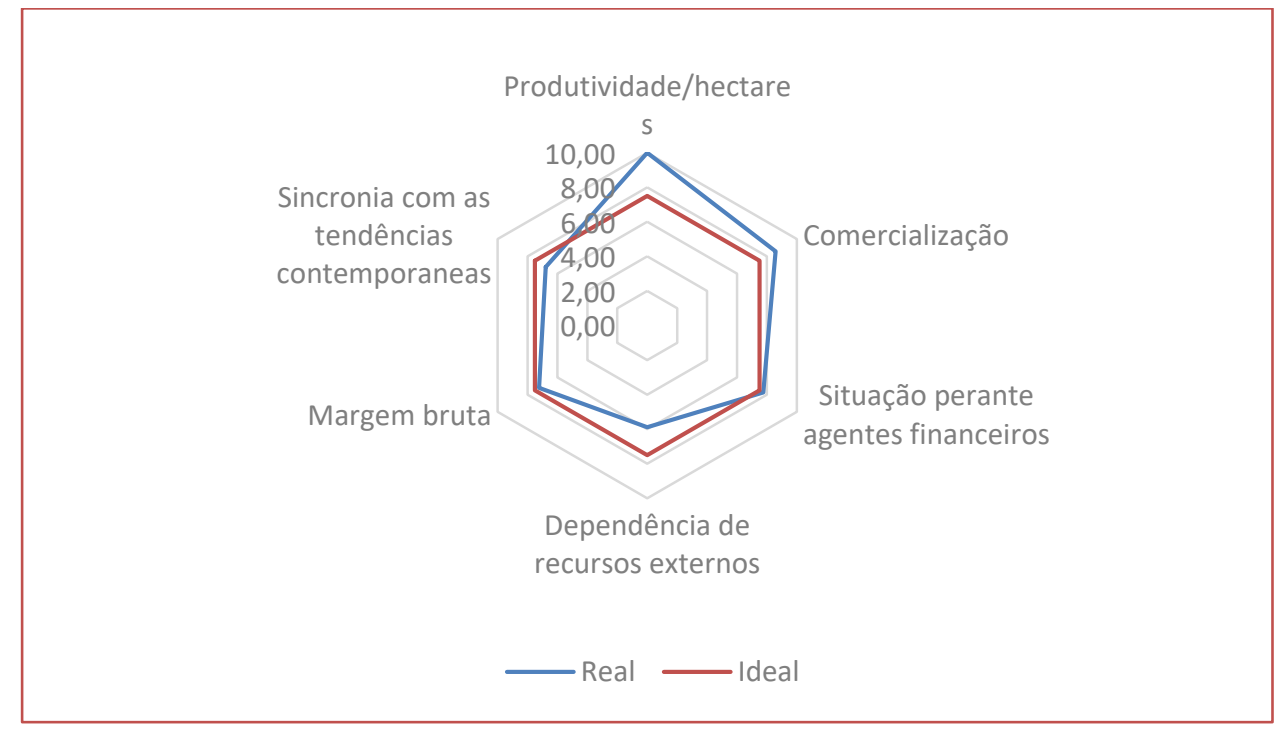

Fonte: Dados da pesquisa, 2018.

A "Produtividade" média das riziculturas, no período em estudo, é de 5.774 toneladas/hectares. Tal produtividade encontra-se acima da produtividade média nacional no mesmo período (5,6 toneladas/hectares), fato que levou este indicador a obter o desempenho máximo de 10 pontos e o peso de 0,41 . Portanto, a produtividade foi o indicador que obteve a nota máxima não só na dimensão econômica mas em todas dimensões estudadas, pois a produção das riziculturas supera a média nacional.

Para Marzall (1999), a base da economia ecológica está vinculada ao desenvolvimento econômico que procura identificar a natureza com o capital fixo, buscando internalizar a preservação ambiental ao custo de produção.

A dimensão social é caracterizada por 4 indicadores (Figura 13): Nível educacional $(2,12)$, métodos participativos $(2,22)$, estrutura da comunidade $(1,20)$ e emprego/renda $(0,61)$. 
Figura 13 - Nível de dimensão social

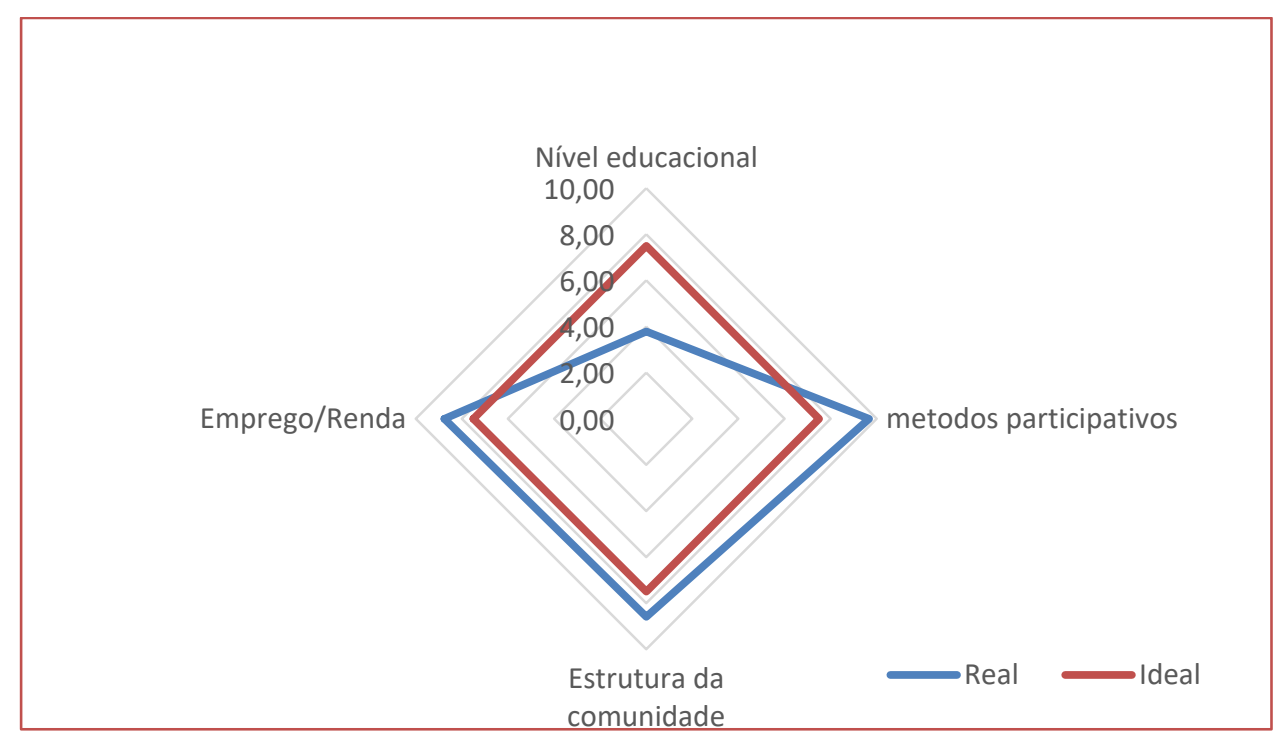

Fonte: Dados de pesquisa, 2018.

A dimensão social apresentou um índice intermediário (6.16), que se encontra acima do índice da dimensão ambiental e abaixo do índice da dimensão econômica. 0 indicador "nível educacional" que é um dos mais importantes da dimensão social (peso 0,56), teve um desempenho alto (2.12) que contribuiu para a elevação do índice. Já o métodos participativos que é o indicador que obteve maior desempenho $(2,22)$, o que contribuiu para que o índice desta dimensão não estivesse acima do encontrado. 


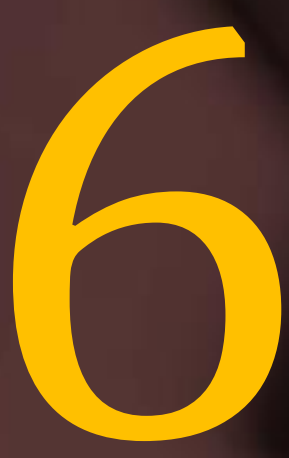

Considerações Finais 


\section{CONSIDERAÇÕES FINAIS}

A seleção de indicadores de sustentabilidade permitiu uma aproximação com a realidade do funcionamento do local referente às dimensões ambiental, social e econômica. Entretanto, o resultado de sustentabilidade demonstraram que a rizicultura pode contribuir para o desenvolvimento socioeconômico da região, se forem adotadas medidas que possam melhorar os indicadores que apresentaram um desempenho baixo, com maior destaque para a dimensão ambiental.

Contudo, os altos níveis de produtividade alcançados não estão acoplados ao desenvolvimento social e ambiental pois a renda dos agricultores é baixa e o nível de degradação ambiental é elevado, como demonstrado pelo seu baixo índice. A legislação que garante o bem estar do agricultor rural não é obedecida na totalidade, razão pela qual a maioria dos indicadores apresentaram um desempenho abaixo do ideal. A dimensão social e econômica apesar de terem apresentado índices intermediários, os seus indicadores também precisam ser melhorados, para que no futuro se tenha um nível de sustentabilidade ideal.

O método AHP foi efetivo para a realização do presente estudo, pois, tornou possível a demonstração realidade da sustentabilidade das propriedades de arroz em Mato Grosso do Sul. Dessa forma, espera-se que os indicadores selecionados e mensurados neste trabalho sirvam de uma base para futuros trabalhos de avaliação da sustentabilidade em oriziculturas do estado de Mato Grosso do Sul para a adoção de práticas e ações que melhorem a sua sustentabilidade. 
Referências 
[1] ANDERSON, D.R. SWEENEY, D.L. WILLIAMS, T. A. Estatística aplicada à administração e economia. São Paulo: pioneira Thomson Learning, 2003. 616 p.

[2] ANDERSON, J. R., DILLON, J. L., HARDAKER, J.B. Agricultural decision analysis. Ames: lowa State University Press, 1977. 344p.

[3] BABBIE, E. Métodos de pesquisa de survey. Belo Horizonte: Editora UFMG, 1997. 519p.

[4] BRAZILIAN RICE. Disponível: https://www.comexdobrasil.com/projeto-brazilian-rice-define-mercadosprioritarios-para-exportacoes-nos-proximos-dois-anos/ Acesso em: 19 de janeiro, 2018.

[5] BRAENDELAND, G., REFSDAL, A., \& STOLEN, K. (2010). Análise Modular e modelagem de cenários de risco com dependências. 0 Jornal de Sistemas e Software, 83, 1995-2013

[6] COELLI, T.; RAHMAN, S.; THIRTLE, C. Technical, allocative, cost and scale efficiencies in Bangladesh rice cultivation: a non-parametric approach. Journal of Agricultural Economics, v. 53, n. 3, p. 607-626, 2002.

[7] COELLI, T. J. et al. An introduction to efficiency and productivity analysis. 2. ed. New York: Springer, 2005.

[8] CONAB - Companhia Nacional de Abastecimento. Brasília, 2018. Safras: séries históricas. Disponível em: <http://www.conab.gov.br/conteudos.php?a=1252\&>. Acesso em: 21 marco 2018.

[9] CONAB. Companhia Nacional de Abastecimento. A cultura do arroz. 2015. Disponível em:

[10] <http://www.conab.gov.br/OlalaCMS/uploads/arquivos/16_03_01_16_56_00_a_cultura_do_arroz__conab.pdf>. Acesso em: 19 de janeiro, 2018.

[11] CRESWELL, J. W.Projeto de pesquisa: método qualitativo, quantitativo e misto. Porto Alegre: Artmed, 2007.

[12] CUI Y, GAlinhAS G, ZHU Y, ZHAO J. Ambiental Índice Sustentabilidade de Shandong, China. Int J Dev Sust mundo em 2004; 11 (3): 227 - 33.

[13] DEVI, K. S.; PONNARASI, T. An economic analysis of modern rice production technology and its adoption behaviour in Tamil Nadu. Agricultural Economics Research Review, v.22, p.341-347, 2009.

[14] DHUNGANA, B. R., NUTHALL, P. L. NARTEA, G. V. Measuring the economic inefficiency of Nepalese rice farms using data envelopment analysis. The Australian Journal of Agricultural and Resource Economics, v. 48, n. 2, p. 347 $369,2004$.

[15] DUTRA, A. Da. S. O processo decisório de implantação de estrutura para armazenagem de soja ao nível de propriedade rural na região de Santo Ângelo/RS. 2008. 118f. Dissertação (Mestrado em Agronegócios) - Programa de Pós Graduação em Agronegócios, Centro de Estudos e Pesquisas em Agronegócios, Universidade Federal do Rio Grande do Sul, Porto Alegre, 2018.

[16] ELKINGTON, J. (2012). Sustentabilidade, canibais com garfo e faca. São Paulo, SP: Makron Books.

[17] ESTY DC, LEVY M, SREBOTNJAK T, DE SHERBININ A. Índice de Sustentabilidade Ambiental: aferição gestão ambiental nacional. New Haven: Yale Center for Law \& Política Ambiental; 2005.

[18] FLATEN, 0. et al. Comparing risk perceptions and risk management in organic and conventional dairy farming: empirical results from Norway. Livestock Production Science, Amsterdam, v. 95, p. 11-25, 2005.

[19] FANG, H-H. et al. A slacks-based measure of super-efficiency in data envelopment analysis: An alternative approach. Omega, v. 41, n. 4, p. 731-734, 2013. 
[20] FAN, S. Technological change, technical and allocative efficiency in Chinese agriculture: The case of rice production in Jiangsu. Journal of International Development, v. 12, n. 1, p. 1, 2000.

[21] FERREIRA, C. M. Sustentabilidade de sistemas de produção de arroz de terras altas. Informações Econômicas, São Paulo, v. 38, n. 11, p. 59-70, nov. 2008.

[22] GASSON, R. Goals and Values of Farmers. Journal of agricultural Economics, Ashford, v. 24(3), p. 521-537. 1973

[23] GIORDANO, Samuel R.; SPERS, Eduardo E. Competividade do sistema agroindustrial do arroz. São Paulo: Pensa/FIA/FEA/USP, 1998.

[24] Gomez-Limon, J., Arriaza, ML, \& Riesgo, L. (2003). Uma análise MCDM de aversão ao risco agrícola. European Journal of Operational Pesquisa, 15, 569-585.

[25] HAIR, J. Fr. et al. Fundamentos de métodos de pesquisa em administração. Porto Alegre: Bookman, 2005, 471p.

[26] Halter AN, \& Dean GW (1971). Decisões sob incerteza com aplicações de pesquisa. ( 1 ed). Cincinnati: SouthWestern Press,(Capítulo 6).

[27] HARDAKER, J.B., HUIRNE, R. B. M., ANDERSON, J. R., LIEN, G. Coping with risk in agriculture. 2 $2^{\mathrm{a}}$ ed. Cambridge: CABI Publishing, 2004.

[28] HARWOOD, J., HEIFNER, R., COBLE, K., PERRY, J., SOMWARU, A. Managing Risk in Farming: Concepts, Research, and Analysis. Market and Trade Economics Division and Resource Economics Division, Economic Research Service, U.S. Department of Agriculture. Agricultural Economic Report No. 774.

[29] HOAG, D. L. Applied Risk Management in Agriculture. Boca Haton: CRC Press, 2009, 419p.

[30] Isik M., \& Khanna M. (2003). Tecnologia estocástica, preferências de risco e adoção de tecnologias específicas do local. American Journal of Economia Agrícola, 85, 305-317.

[31] IBGE - Instituto Brasileiro de Geografia e Estatística. Banco de dados agregados: tabela 1618 - área plantada, área colhida e produção, por ano da safra e produto. 2016a. Disponível em: <http://www.sidra.ibge.gov.br/bda/tabela/protabl.asp?c=1618\&z=t\&o=26\&i=P>. Acesso em: 25 maio 2016.

[32] __ Banco de dados agregados: tabela 188 - rendimento médio, por ano da safra e produto. $2016 \mathrm{~b}$. Disponível em:

[33] <http://www.sidra.ibge.gov.br/bda/tabela/protabl.asp?c=188\&z=t\&o=26\&i=P>. Acesso em: 25 marco 2019.

[34] IRGA - Instituto Rio Grandense do Arroz. Produtividades municipais - safra 2014/15. 2016a. Disponível em: <http://www.irga.rs.gov.br/upload/20150710145210produtividade_municipios_safra_14_15.pdf>. Acesso em: 21 marco 2019.

[35] _. Produtividades municipais - safra 2015/16. 2016b. Disponível em: <http://www.irga.rs.gov.br/upload/20160628092753produtividade_municipios_safra_15_16.pdf>. Acesso em: 16 marco 2019.

[36] JUWANA I, PERERA B, MUTTIL N. Um índice de sustentabilidade da água para West Java-Parte 2: refining a estrutura conceitual utilizando a técnica Delphi. Água Sci Technol 2010a; 62 (7): 1641 - 52.

[37] JUWANA I, PERERA B, MUTTIL N. Um índice de sustentabilidade da água para West Java. Parte 1: developing o quadro conceptual. Água Sci Technol 2010b; 62 (7): 1629 - 40. 
[38] JUWANA I, PERERA BJC, Índice de Sustentabilidade Água Muttil N. West Java - um estudo de caso sobre Citarum captação. Trabalho apresentado no 19o Mundial IMACS /Congresso MODSIM, Cairns, Austrália; 2011.12 16de dezembro de 2011. Kodikara PN. operação otimizada multi-objetivo de sistemas de abastecimento de água urbanos. Docção A publicação electrónica; Texto completo disponível em formato PDF; resumo.

[39] KIMURA, H. Administração de riscos em empresas agropecuárias e agroindustriais. Cadernos de Pesquisas em Administração, São Paulo, v.1, n.7, p. 51-61. 1998.

[40] KNIGHT, F. H. Risk, uncertainty and profit. Nova Iorque: Augustus M. Kelley, 1964. Acesso em: 14 abril. 2019. Disponível em: https://mises.org/sites/default/files/Risk,\%20Uncertainty,\%20and\%20Profit_4.pdf

[41] LAWRENCE P, MEIGH J, SULLIVAN C. $O$ índice de pobreza de água: uma comparação internacional. Retirado 25 de julho de 2018, a partir de http://www.keele.ac.uk/depts/ec/wpapers/kerp0219. pdf 2003.

[42] MEUWISSEN, M. P.; HUIRNE, R. B. M.; HARDAKER, J. B. Risk and risk management: an empirical analysis of Dutch livestock farmers. Livestock Production Science. Amsterdam. V. 69, p. 43-53, 2001.

[43] NARGIS, F. et al. Efficiency analysis of boro rice production in North-Central region of Bangladesh. The Journal of Animal \& Plant Sciences, v. 23, n.2, p. 527-533, 2013.

[44] NAHAS, MARIA INÊS PEDROSA; GONÇALVES, ÉBER; SOUZA, RENATA GUIMARÃES VIEIRA DE; VIEIRA, CARINE MARTINS. Sistemas de indicadores municipais no Brasil: experiências e metodologias. In: XV Encontro Nacional de Estudos Populacionais, ABEP. Caxambu - MG - Brasil, $2006 . \quad$ Disponível em<http://www.abep.nepo.unicamp.br/encontro2006/docspdf/ABEP2006_529.pdf>. Acesso em 25 set.2018.

[45] NELSON, G. A. Teaching agricultural producers to consider risk in decision-making. Faculty Paper 97-17. College Station, Texas: Texas A\&M University, 1997.

[46] REZENDE, M.L.; SILVA, B.B.; LOPES, M.M.; SALGADO, E.G.; SANTOS, B.R. Análise de risco e viabilidade econômica do plantio de mogno africano no sul de Minas Gerais. Custos e @gronegócios online, v. 14,. Edição Especial, /Dez - 2018., 314-331.

[47] RICHARDSON, J.W., HERBEST, B.K.; OUTLAW, J.L.; GILL II, R.C. Including risk in economic feasibility analyses: the case of ethanol production in Texas, J. Agribusiness, v.25, n.2, 2007.

[48] RIBEIRO, HELENA, JAIME, PATRÍCIA CONSTANTE, \& VENTURA, DEISY. (2017). Alimentação e sustentabilidade. Estudos Avançados, 31(89), 185-198. https://dx.doi.org/10.1590/s0103-40142017.31890016.

[49] RICHARDSON, J.W., Simulation for Applied Risk Management, Department of Agricultural Economics, Agricultural and Food Policy Center, Texas A\&M University, College Station, Texas, 2006.

[50] SAMBUICHI, R. H. R.; CONSTANTINO DE OLIVEIRA, M. A.; MOREIRA DA SILVA, A. P.; LUEDEMANN, G. (2012): A sustentabilidade ambiental da agropecuária brasileira: Impactos, políticas públicas e desafios, Texto para Discussão, Instituto de Pesquisa Econômica Aplicada (IPEA), No. 1782, Instituto de Pesquisa Econômica Aplicada (IPEA), Brasília.

[51] SIMON, H. A. Models of man: social and rational. New York: John Willey and Sons, Inc., 1957. 279p.

[52] SOSBAI. Sociedade Sul-Brasileira de Arroz Irrigado. Arroz Irrigado: recomendações técnicas da pesquisa para o Sul do Brasil. Porto Alegre, RS, 2010. 188 p.

[53] SOUZA, D.; SBARDELOTTO, A. F.; ZIEGLER, D. R.; MARCZAK, L. D. F.; TESSARO, I. C. Characterization of rice starch and protein obtained by a fast alkaline extraction method. Food Chemistry, v. 191, p. 36-44, January 2016. 
[54] SOUZA, J. G. M.; NASCIMENTO, A. A.; SOUSA, R. R. C.; CAMPOS, N. S.; ALMEIDA, A. R. S. S. M. Incerteza da viabilidade econômica de um projeto portuário: uma aplicação da simulação Monte Carlo. Revista Eletrônica Gestão \& Saúde, v. 6, p. 1042-1056, 2015.

[55] SULLIVAN C, MEIGH J, LAWRENCE P. Aplicação do índice pobreza em água diferente escalas: um conto preventivo. Int água de 2006; 31 (3): 412 - 26.

[56] WALTER, M.; MARCHEZAN, E.; AVILA, L. A. Arroz: composição e características nutricionais. Ciência Rural, Santa Maria, v. 38, n. 4, p. 1184-1192. jul. 2008

[57] WANDER, A. E.; DA SILVA, O. F. Rentabilidade da produção de arroz no Brasil. Embrapa Arroz e Feijão, Brasília, 2014.

[58] WATKINS, K. B. et al. Measuring Technical, Allocative, and Economic Efficiency of Rice Production in Arkansas using Data Envelopment Analysis. In: Annual Meeting, p. 2-5, feb., 2013.

[59] TUN, YuYu; KANG, Hye-Jung. An analysis on the factors affecting rice production efficiency in Myanmar. Journal of East Asian Economic Integration. v. 19, n. 2, p. 167-188, jun., 2015.

[60] TU, V. H.; TRANG, N. T. Cost efficiency of rice production in Vietnam: an application of stochastic translog variable cost frontier. Asian Journal of Agricultural Extension, Economics \& Sociology, v. 8, n. 1, p. 1-10, 2016.

[61] VAN ITTERSUM MK, EWERT F, HECKELEI T, J WERY, ALKAN OLSSON J, ANDERSEN E, ET AL. Inter avaliação ralado dos sistemas agrícolas: um framework baseado em componentes para a União Europeia (seamless). Agr Syst 2008; 96 (1 - 3): 150 - 65. 


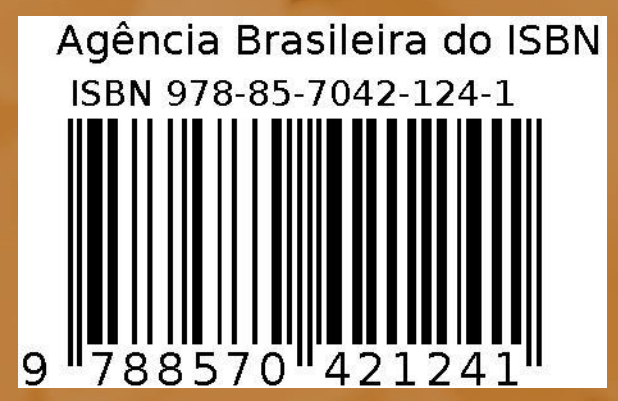

